\title{
PENERAPAN METODE PEMBERIAN BALIKAN \\ UNTUK MENINGKATKAN KOMPETENSI MENGATUR PERJALANAN BISNIS PADA SISWA KELAS XII APk-2 SMK NEGERI 1 MAGETAN TAHUN PELAJARAN 2014/2015
}

\author{
Arum Yuliani \\ SMK Negeri 1 Magetan \\ roem.nugraha@gmail.com
}

\begin{abstract}
This study examines the problem of how to increase learning activities and the competence of Organizing Business Travel through the application of the Proposal Method for class XII students of SMK Negeri 1 Magetan in the 2014/2015 academic year. The purpose of this research is to find out the increase in activities and competencies in arranging business trips through the application of the feedback method to class XII students of SMK Negeri 1 Magetan in the 2014/2015 academic year. This research is a classroom action research study consisting of two cycles. Each cycle consists of four stages, namely (1) planning, (2) implementation, (3) observation, and (4) reflection. The subjects of this study were students of class XII APk-2 SMK Negeri 1 Magetan in the odd semester of the 2014/2015 academic year. Data obtained from the results of tests and observations made in cycle I and cycle II. From the results of the analysis of these data, it is known that student competency shown by classical learning completeness is achieved and student learning activities have also increased from cycle I to cycle II. The conclusion of this research is the application of the method of giving feedback can increase learning activities and competence in arranging business trips for class XII students of SMK Negeri 1 Magetan 2014/2015 Academic Year.
\end{abstract}

Keywords: Method of Giving Feedback, Learning Activities, Competencies

\begin{abstract}
Abstrak
Penelitian ini mengkaji permasalahan tentang bagaimana peningkatan aktivitas belajar dan kompetensi Mengatur Perjalanan Bisnis melalui penerapan metode Pemberian Balikan pada siswa kelas XII SMK Negeri 1 Magetan tahun pelajaran 2014/2015. Adapun tujuan dari penelitian ini adalah untuk mengetahui peningkatan aktivitas dan kompetensi Mengatur Perjalanan Bisnis melalui penerapan metode Pemberian Balikan pada siswa kelas XII SMK Negeri 1 Magetan tahun pelajaran 2014/2015. Penelitian ini berupa penelitian tindakan kelas yang terdiri dari dua siklus. Setiap siklus terdiri dari empat tahap yaitu: (1) perencanaan, (2) pelaksanaan, (3) pengamatan, dan (4) refleksi. Subyek penelitian ini adalah siswa kelas XII APk-2 SMK Negeri 1 Magetan pada semester ganjil tahun pelajaran 2014/2015. Data diperoleh dari hasil tes dan hasil pengamatan yang dilakukan pada siklus I dan siklus II. Dari hasil analisis terhadap data tersebut, diketahui bahwa kompetensi siswa yang ditunjukkan dengan ketuntasan belajar secara klasikal tercapai dan aktivitas belajar siswa juga mengalami peningkatan dari siklus I ke siklus II. Simpulan dalam penelitian ini adalah penerapan metode pemberian balikan dapat meningkatkan aktivitas belajar dan kompetensi Mengatur Perjalanan Bisnis pada siswa kelas XII SMK Negeri 1 Magetan Tahun Pelajaran 2014/2015.
\end{abstract}

Kata Kunci: Metode Pemberian Balikan, Aktivitas Belajar, Kompetensi 


\section{PENDAHULUAN}

Salah satu bentuk tanggung jawab seorang guru yang mengajar di Sekolah Menengah Kejuruan (SMK) adalah menyiapkan siswa untuk siap memasuki dunia kerja. Tentu tidak mudah mewujudkannya karena memerlukan usaha yang sungguh-sungguh, terutama dalam hal memberikan pembelajaran yang mengarah pada pembentukan kompetensi-kompetensi yang sesuai dengan standar kompetensi yang ditetapkan sehingga dapat dijadikan bekal bagi siswa untuk memasuki dunia kerja. Hal ini sejalan dengan Kurikulum Berbasis Kompetensi (KBK) yang ditetapkan oleh pemerintah pada tahun 2004 yang menekankan pada pengembangan kemampuan melakukan (kompetensi) tugas-tugas dengan standar performansi tertentu, sehingga hasilnya dapat dirasakan oleh peserta didik, berupa penguasaan terhadap seperangkat kompetensi tertentu (Mulyasa, 2006:39). Oleh karena itu kegiatan pembelajaran perlu diarahkan untuk membantu peserta didik menguasai sekurang-kurangnya tingkat kompetensi minimal, agar mereka dapat mencapai tujuan-tujuan yang telah ditetapkan (Mulyasa, 2006:40). Kegiatan pembelajaran juga harus diarahkan untuk memberdayakan semua potensi peserta didik untuk menguasai kompetensi yang diharapkan dan mengembangkan kemampuan untuk mengetahui, memahami, melakukan sesuatu, hidup dalam kebersamaan dan mengaktualisasikan diri (Majid, 2008: 24). Kegiatan pembelajaran yang diharapkan dapat mengarah pada pembentukan kompetensi sebagaimana diuraikan di atas, ternyata tidak selalu berjalan dengan lancar atau tanpa suatu kendala. Kurikulum Berbasis Kompetensi yang menempatkan peran guru dalam kegiatan pembelajaran sebagai fasilitator dan sekaligus sebagai motivator, tidak serta merta dapat dengan mudah dilaksanakan oleh para guru. Masih banyak guru yang merasa kesulitan untuk memfasilitasi cara belajar siswanya agar mereka aktif dalam kegiatan pembelajaran. Tidak sedikit pula guru yang tidak mempunyai kemampuan untuk memotivasi siswanya agar mereka berperan aktif dalam kegiatan pembelajaran. Akibatnya, kegiatan pembelajaran yang dilakukan oleh guru, kurang memberikan kontribusi bagi pembentukan kompetensi siswa.

Permasalahan di atas juga dialami oleh peneliti pada saat mengajar standar kompetensi Mengatur Perjalanan Bisnis di kelas XII APk-2 SMK Negeri 1 Magetan pada semester ganjil tahun pelajaran 2014/2015. Peneliti merasa kesulitan dalam memfasilitasi cara belajar siswa dan memberikan motivasi agar mereka aktif dalam kegiatan pembelajaran. Akibatnya adalah ketika diadakan tes terhadap 40 siswa yang ada di kelas tersebut, diketahui siswa yang memperoleh nilai di atas KKM yang ditetapkan yaitu 75,00 hanya sekitar 22 siswa, atau sekitar 55\%. Hal ini berarti pencapaian kompetensi siswa masih rendah. Selain itu dari data hasil pengamatan terhadap aktivitas siswa pada saat mengikuti kegiatan pembelajaran, mereka kurang antusias.

Peneliti sudah berupaya mencari solusi agar kesulitan itu dapat diatasi, salah satunya dengan melaksanakan kegiatan penilaian yang berupa pemberian tes, latihan atau tugas. Penilaian yang dilakukan ini diharapkan bisa mengkondisikan siswa untuk rajin belajar dan sekaligus aktif dalam kegiatan pembelajaran sehingga mereka dapat mencapai kompetensi pada standar kompetensi yang ditetapkan. Hal ini sesuai dengan pendapat Hamalik (2006: 167) yang menyatakan “...penilaian secara kontinyu akan mendorong murid-murid untuk belajar". Adapun menurut pendapat Djamarah (2006:153-155) "pemilihan bentuk motivasi yang akurat dapat pula dilakukan di antaranya adalah dengan: (1) memberi tugas, (2) memberi ulangan, dan (3) mengetahui hasil”. 
Penilaian berupa pemberian tes, latihan atau tugas jika tidak dikelola dengan baik, juga tidak akan berdampak positip pada pencapaian kompetensi maupun peningkatan kompetensi siswa. Misalnya frekuensi pemberian tes, latihan atau tugas yang kurang, latihan atau tugas yang terlalu sulit untuk dikerjakan, tidak ada kriteria penilaian dan batas waktu yang jelas, kurang telaten dalam membimbing siswa pada saat mengerjakan, tidak ada umpan balik, dan tak jarang pula dijumpai guru tidak mengoreksi latihan atau tugas yang dikerjakan oleh siswa. Kadang guru hanya menyalahkan hasil latihan atau tugas yang dikerjakan oleh siswa tanpa memberi informasi bagaimana memperbaiki kesalahan tersebut. Tentu saja hal ini menyebabkan siswa menjadi malas, mengerjakan latihan atau tugas dengan tidak bersungguhsungguh, banyak melakukan kesalahan, kurang memperhatikan kebersihan dan kerapian, kurang mandiri, tidak tepat waktu, dan terkadang mereka tidak mengerjakan latihan atau tugas tersebut. Akibatnya pencapaian kompetensi siswa rendah. Padahal seharusnya melalui pemberian latihan atau tugas, siswa akan melatih kompetensinya agar ia benar-benar menguasai atau kompeten pada standar kompetensi yang dipelajarinya dan melalui pemberian tes, siswa akan termotivasi untuk mempelajari kompetensi tersebut dengan sebaik-baiknya.

Dari beberapa metode yang pernah peneliti pelajari, salah satu yang memungkinkan untuk dilakukan agar kegiatan pembelajaran khususnya dalam hal pemberian penilaian berdampak positip bagi peningkatan kompetensi siswa yaitu metode pemberian balikan. Pengertian dari pemberian balikan menurut pendapat Hill (1980) dalam Rustiyah (1991: 23) merupakan interaksi antara guru dan siswa yang digunakan sebagai koreksi terhadap jawaban siswa dalam mengerjakan tes atau latihan agar siswa tahu apakah jawabannya dalam mengerjakan tes atau latihan menjawab soal-soal itu benar atau salah. Pendapat lain dikemukakan oleh Benne, dkk (1975) dalam Rustiyah (1991: 23) yang menyatakan bahwa dengan pemberian balikan siswa akan mengetahui kesalahan/ kekurangan dan penilain serta komentar yang diberikan oleh guru tentang tampilannya dalam mengerjakan tes atau latihan dengan maksud agar memudahkan siswa dalam memperbaikinya. Kesimpulannya, pemberian balikan adalah umpan balik yang berupa informasi atau pemberitahuan guru kepada siswa baik secara lisan atau tertulis terhadap salah benarnya jawaban siswa dari hasil mengerjakan tes, latihan atau tugas setelah selesai mengikuti program pembelajaran yang dirumuskan oleh guru dengan tujuan agar siswa termotivasi untuk berusaha memperbaiki kesalahan tersebut.

Pemberian balikan ini merupakan salah satu wujud apresiasi guru terhadap usaha siswa dalam mengerjakan tes, latihan atau tugas dengan cara memberikan umpan balik, khususnya yang bersifat positip. Hal ini tentu akan membuat siswa merasa diperhatikan dan dihargai sehingga dapat meningkatkan motivasinya untuk mengerjakan tes, latihan atau tugas dengan sebaik-baiknya. Peningkatan motivasi ini diharapkan dapat berpengaruh pada peningkatan kompetensinya. Hamalik (2006: 166-167) menyatakan “.... pemberian pujian kepada murid atas hal-hal yang telah dilakukan dengan berhasil besar manfaatnya sebagai pendorong belajar....”.

\section{A. Motivasi Belajar}

Motivasi dalam bentuk apapun sangat diperlukan jika kita akan melakukan sesuatu. Motivasi yang kita miliki akan menambah semangat bagi kita untuk melakukan sesuatu tersebut, begitu juga halnya dalam kegiatan belajar. Namun, motivasi yang dimiliki oleh seseorang tidaklah selalu sama dengan orang lain meskipun kegiatan yang dilakukan sama. Misalnya, dalam kegiatan belajar di sekolah, 
motivasi yang dimiliki oleh setiap siswa berbeda satu sama lain. Ada yang mengatakan motivasinya karena ingin mendapatkan nilai yang baik, agar disayang oleh guru, takut dimarahi orang tua jika tidak belajar, dan lainlain.

Menurut pendapat Makmun (2007:37) motivasi adalah suatu kekuatan atau tenaga atau daya atau keadaan yang kompleks dan kesiapsediaan dalam diri individu untuk bergerak ke arah tujuan tertentu, baik disadari ataupun tidak disadari. Secara sederhana Hamalik (2003:158) merumuskan pengertian motivasi adalah perubahan energi dalam diri (pribadi) seseorang yang ditandai dengan timbulnya perasaan dan reaksi untuk mencapai tujuan. Berdasarkan dua pendapat tersebut dapat disimpulkan bahwa motivasi adalah suatu kekuatan yang memberikan energi pada diri seseorang untuk bergerak ke arah tujuan tertentu. Hakikat belajar dikemukakan oleh Djamarah (2006:38) sebagai suatu "perubahan" yang terjadi dalam diri seseorang setelah berakhirnya melakukan aktivitas belajar. Jadi dapat disimpulkan bahwa motivasi belajar adalah suatu kekuatan yang memberikan energi pada diri seseorang untuk melakukan "perubahan" pada dirinya setelah berakhirnya melakukan aktivitas belajar.

\section{Hal-Hal yang Dapat Meningkatkan Motivasi Belajar}

Motivasi belajar yang dimiliki oleh setiap siswa sebagaimana yang telah dikemukakan sebelumnya berbeda satu sama lain. Begitu pentingnya motivasi belajar ini bagi berhasilnya kegiatan belajar mengajar, membawa konsekuensi bagi guru untuk selalu menumbuhkan dan meningkatkan sehingga akan tercipta suasana belajar yang aktif dan menyenangkan bagi siswa. Peneliti sangat setuju dengan pendapat dari Hamalik (2006: 166-167) dalam bukunya Strategi Belajar Mengajar yang mengatakan bahwa "guru dapat menggerakkan atau membangkitkan motivasi belajar siswa dengan cara antara lain: (1) memberi angka, karena umumnya siswa ingin mengetahui hasil pekerjaannya yakni berupa angka yang diberikan oleh guru, (2) memberi pujian yaitu pemberian pujian kepada murid atas hal-hal yang telah dilakukan dengan berhasil besar manfaatnya sebagai pendorong belajar, dan (3) penilaian secara kontinyu akan mendorong murid-murid untuk belajar".

Pemilihan bentuk motivasi yang akurat menurut pendapat Djamarah (2006:153-155) dapat pula dilakukan di antaranya adalah dengan: (1) memberi tugas, (2) memberi ulangan, dan (3) mengetahui hasil. Tugas adalah suatu pekerjaan yang menuntut untuk diselesaikan setelah siswa mendapat bahan pelajaran sehingga mereka akan memperhatikan penyampaian bahan pelajaran karena mengetahui bahwa setelah itu mereka akan mendapatkan tugas. Memberi ulangan dilakukan guru untuk mendapatkan umpan balik dari anak didik.

Biasanya anak didik akan giat belajar baik di sekolah atau di rumah ketika diketahuinya akan dilaksanakan ulangan. Mengetahui hasil adalah suatu sifat yang sudah melekat di dalam diri setiap orang demikian pula anak didik. Setiap tugas yang telah diselesaikan oleh anak didik dan telah diberi angka (nilai) sebaiknya, guru bagikan kepada setiap anak didik agar mereka dapat mengetahui prestasi kerjanya.

\section{B. Penilaian}

\section{Pengertian Penilaian}

Penilaian adalah kegiatan yang tidak bisa dilepaskan dari proses belajar mengajar. Melalui penilaian guru akan mengetahui sejauh mana siswa dapat menguasai kompetensi yang diajarkan oleh guru. Baik buruknya pencapaian kompetensi oleh siswa dapat dijadikan sebagai ukuran berhasil atau tidaknya guru di dalam mengelola pembelajaran. 
Dari hasil penilaian ini pula guru dapat mengambil tindakan-tindakan yang dapat memperbaiki pengelolaan pembelajarannya. Setidak-tidaknya jika hal ini dilakukan maka guru telah memberikan salah satu solusi bagi permasalahan rendahnya pencapaian kompetensi siswa.

Menurut Sudjana ( 2006: 2) penilaian adalah suatu tindakan atau kegiatan untuk melihat sejauh mana tujuan-tujuan instruksional telah dapat dicapai atau dikuasai oleh siswa dalam bentuk hasil-hasil belajar yang diperlihatkannya setelah menempuh proses belajar mengajar. Safary (2005: 1-2) dalam bukunya yang berjudul Penulisan Butir Soal Berdasarkan Penilaian Berbasis Kompetensi menuliskan bahwa berdasarkan kurikulum 2004, penilaian (assessment) adalah kegiatan untuk mengetahui apakah suatu program telah berhasil dengan efisien dan efektif atau tidak. Penilaian berbasis kelas adalah kegiatan yang dilakukan untuk memperoleh dan mengefektifkan informasi tentang hasil belajar siswa pada tingkat kelas selama dan setelah kegiatan belajar mengajar. Berdasarkan beberapa pendapat tersebut, disimpulkan bahwa penilaian adalah suatu kegiatan yang dilakukan untuk menjawab pertanyaan tentang sebaik apa hasil atau prestasi belajar seorang siswa.

Hasil penilaian dapat berupa nilai kualitatif (pernyataan naratif dalam katakata) dan nilai kuantitatif (berupa angka). Hasil penilaian ini diperoleh dari tes yang dilakukan oleh guru terhadap siswa. Sudjana (2006:35) berpendapat sebagai berikut: Tes sebagai alat penilaian adalah pertanyaanpertanyaan yang diberikan kepada siswa untuk mendapat jawaban dari siswa dalam bentuk lisan, bentuk tulisan, atau dalam bentuk perbuatan. Secara khusus, dalam konteks pembelajaran di kelas, penilaian dilakukan untuk mengetahui kemajuan dan hasil belajar siswa, mendiagnosa kesulitan belajar, memberikan umpan balik/perbaikan proses belajar mengajar, dan penentuan kenaikan kelas. Melalui penilaian dapat diperoleh informasi yang akurat tentang penyelenggaraan pembelajaran dan keberhasilan belajar peserta didik, guru, serta proses pembelajaran itu sendiri. Berdasarkan informasi itu, dapat dibuat keputusan tentang pembelajaran, kesulitan siswa dan upaya bimbingan yang diperlukan serta keberadaan kurikulum itu sendiri.

\section{Tujuan Penilaian}

Penilaian memiliki tujuan yang sangat penting dalam pembelajaran. Dari hasil penilaian ini akan diketahui beberapa hal yang dapat dipergunakan sebagai alat ukur untuk menentukan berhasil atau tidaknya suatu pembelajaran. Tujuan penilaian ini adalah untuk mengetahui prestasi belajar, diagnostik atau seleksi (Safary, 2005:18). Menurut pendapat Sudjana (2006: 4) tujuan penilaian adalah (1) mendeskripsikan kecakapan belajar para siswa sehingga dapat diketahui kelebihan dan kekurangannya dalam berbagai bidang studi atau mata pelajaran yang ditempuhnya, (2) menentukan tindak lanjut hasil penilaian, yakni melakukan perbaikan dan penyempurnaan dalam hal program pendidikan dan pengajaran serta strategi pelaksanaannya, dan (3) memberikan pertanggungjawaban (accountability) dari pihak sekolah kepada pihak-pihak yang berkepentingan. Sudrajat (2014) menyebutkan tujuan dari penilaian adalah:

1) Sebagai grading, penilaian ditujukan untuk menentukan atau membedakan kedudukan hasil kerja peserta didik dibandingkan dengan peserta didik lain. Penilaian ini akan menunjukkan kedudukan peserta didik dalam urutan dibandingkan dengan anak yang lain. Karena itu, fungsi penilaian untuk grading ini cenderung membandingkan anak dengan anak yang lain sehingga lebih mengacu kepada penilaian acuan norma (norm-referenced assessment). 
2) Sebagai alat seleksi, penilaian ditujukan untuk memisahkan antara peserta didik yang masuk dalam kategori tertentu dan yang tidak. Peserta didik yang boleh masuk sekolah tertentu atau yang tidak boleh. Dalam hal ini, fungsi penilaian untuk menentukan seseorang dapat masuk atau tidak di sekolah tertentu.

3) Untuk menggambarkan sejauh mana seorang peserta didik telah menguasai kompetensi.

4) Sebagai bimbingan, penilaian bertujuan untuk mengevaluasi hasil belajar peserta didik dalam rangka membantu peserta didik memahami dirinya, membuat keputusan tentang langkah berikutnya, baik untuk pemilihan program, pengembangan kepribadian maupun untuk penjurusan.

5) Sebagai alat diagnosis, penilaian bertujuan menunjukkan kesulitan belajar yang dialami peserta didik dan kemungkinan prestasi yang bisa dikembangkan. Ini akan membantu guru menentukan apakah seseorang perlu remidiasi atau pengayaan.

6) Sebagai alat prediksi, penilaian bertujuan untuk mendapatkan informasi yang dapat memprediksi bagaimana kinerja peserta didik pada jenjang pendidikan berikutnya atau dalam pekerjaan yang sesuai. Contoh dari penilaian ini adalah tes bakat skolastik atau tes potensi akademik.

Dari beberapa tujuan penilaian yang telah diuraikan di depan maka tujuan untuk melihat tingkat penguasaan kompetensi, bimbingan, dan diagnostik merupakan peranan utama dalam penilaian. Lebih lanjut dapat dikatakan bahwa penilaian membawa konsekuensi bagi guru agar secara langsung atau tak langsung mampu melaksanakan penilaian dalam keseluruhan proses pembelajaran.

\section{Jenis-Jenis Penilaian}

Untuk menilai sejauh mana siswa telah menguasai beragam kompetensi, berbagai jenis penilaian perlu diberikan sesuai dengan kompetensi yang akan dinilai, seperti unjuk kerja/kinerja (performance), penugasan (proyek), hasil karya (produk), kumpulan hasil kerja siswa (portofolio), dan penilaian tertulis (paper and pencil test). Jadi, tujuan penilaian adalah memberikan masukan informasi secara komprehensif tentang hasil belajar peserta didik, baik dilihat ketika saat kegiatan pembelajaran berlangsung maupun dilihat dari hasil akhirnya, dengan menggunakan berbagai cara penilaian sesuai dengan kompetensi yang diharapkan dapat dicapai peserta didik (Sudrajat, 2014).

\section{Pendekatan Penilaian}

Ada dua pendekatan yang dapat digunakan dalam melakukan penilaian hasil belajar, yaitu penilaian yang mengacu kepada norma (Penilaian Acuan Norma atau normreferenced assessment) dan penilaian yang mengacu kepada kriteria (Penilaian Acuan Kriteria atau criterion referenced assessment) (Akhmad Sudrajat:2014). Perbedaan kedua pendekatan tersebut terletak pada acuan yang dipakai. Pada penilaian yang mengacu kepada norma, interpretasi hasil penilaian peserta didik dikaitkan dengan hasil penilaian seluruh peserta didik yang dinilai dengan alat penilaian yang sama. Jadi hasil seluruh peserta didik digunakan sebagai acuan. Sedangkan, penilaian yang mengacu kepada kriteria atau patokan, interpretasi hasil penilaian bergantung pada apakah atau sejauh mana seorang peserta didik mencapai atau menguasai kriteria atau patokan yang telah ditentukan. Kriteria atau patokan itu dirumuskan dalam kompetensi atau hasil belajar dalam kurikulum berbasis kompetensi.

Pada pelaksanaan kurikulum berbasis kompetensi, pendekatan penilaian yang digunakan adalah penilaian yang mengacu 
kepada kriteria atau patokan. Dalam hal ini prestasi peserta didik ditentukan oleh kriteria yang telah ditetapkan untuk penguasaan suatu kompetensi. Meskipun demikian, kadangkadang dapat digunakan penilaian acuan norma, untuk maksud khusus tertentu sesuai dengan kegunaannya, seperti untuk memilih peserta didik masuk rombongan belajar yang mana, untuk mengelompokkan peserta didik dalam kegiatan belajar, dan untuk menyeleksi peserta didik yang mewakili sekolah dalam lomba antar-sekolah.

\section{Pemberian Balikan}

\section{Pengertian Pemberian Balikan}

Mengutip beberapa pandangan, Rustiyah (1991: 23) mengemukakan tentang pengertian pemberian balikan sebagai berikut:

a. Pemberian Balikan adalah pemberian informasi kepada siswa tentang hasil kerjanya dalam mengerjakan tes atau latihan (Cardelle dan Corno, 1985: 162-173).

b. Pemberian Balikan adalah pemberian informasi kepada peserta didik sampai sejauh mana ia telah mencapai tujuan pembelajaran yang telah dirumuskan (Dawdan Gage, 1967: 181-188).

c. Pemberian Balikan adalah pemberian informasi kepada siswa seberapa jauh ia telah memahami isi pembelajaran sesuai dengan tes dan latihan yang diberikan guru kepadanya (Kulik dan Kulik, 1988: 79-97).

d. Pemberian Balikan adalah suatu komunikasi antara guru dan siswa dalam hal memudahkan siswa memperbaiki kekurangannya dalam proses pembelajaran (Measn, dkk, 1978: 373387).

e. Pemberian Balikan adalah pemberian informasi kepada siswa tentang pemahamannya dalam mengerjakan tes atau latihan setelah menyelesaikan suatu topik atau satu sub pokok bahasan yang diberikan guru setelah selang waktu tertentu (Rochim dan Thomson, 1985: 368-372).

f. Pemberian Balikan adalah salah satu cara untuk memudahkan siswa belajar, yaitu memberi informasi kepada siswa tentang hasil kerjanya dalam mengerjakan tes atau latihan (Anderson dan Faust, 1973:271-295).

g. Pemberian balikan adalah merupakan interaksi antara guru dan siswa yang digunakan sebagai korekasi terhadap jawaban siswa dalam mengerjakan tes atau latihan agar siswa tahu apakah jawabannya dalam mengerjakan tes atau latihan menjawab soal-soal itu benar atau salah (Hill, 1980).

h. Benne, dkk, (1975) menyatakan bahwa dengan Pemberian Balikan siswa akan mengetahui kesalahan/ kekurangan dan penilaian serta komentar yang diberikan oleh guru tentang tampilannya dalam mengerjakan tes atau latihan dengan maksud agar memudahkan siswa dalam memperbaikinya.

i. Pemberian Balikan adalah informasi yang diberikan kepada siswa setelah ia memberikan respon atas tes atau latihan yang diberikan guru setelah melakukan proses pembelajaran sesuai dengan program yang dirancang oleh guru (Skodmore, dkk. 1979: 89).

Dari beberapa pengertian yang telah diuraikan tersebut, dapat disimpulkan bahwa pengertian pemberian balikan adalah informasi atau pemberitahuan guru kepada siswa baik secara lisan atau tertulis terhadap salah benarnya jawaban siswa dari hasil mengerjakan tes, latihan atau tugas setelah selesai mengikuti program pembelajaran yang dirumuskan oleh guru dengan tujuan agar siswa terangsang atau 
termotivasi untuk berusaha merespon untuk mencari pembetulan.

\section{Langkah-Langkah Pemberian Balikan}

Menurut Rustiyah (1991: 24) ada dua cara pemberian balikan, yaitu:

a. Pemberian Balikan Secara Simbol

Pemberian Balikan secara simbol adalah pemberian informasi guru kepada siswa secara tertulis yang dituangkan pada lembar jawaban hasil kerja siswa dalam mengerjakan tes atau latihan, dengan memberikan tanda benar (B) pada jawaban yang benar, dan memberikan tanda salah (S) pada jawaban yang salah tanpa memberikan keterangan apapun. Tandatanda tersebut sebagai simbol apakah pekerjaan siswa benar atau salah.

b. Pemberian Balikan Secara Ekspositorik

Pemberian Balikan secara ekspositorik, adalah pemberian informasi guru kepada siswa secara tertulis yang dituangkan pada lembar jawaban hasil kerja siswa dalam mengerjakan tes atau latihan, yaitu dengan memberikan tanda benar (B) pada jawaban yang benar, dan memberikan tanda salah (S) pada jawaban yang salah dan sekaligus memberi penjelasan singkat/terperinci atas kesalahannya dan petunjuk perbaikan serta buku sumber acuannya agar siswa dapat memperbaiki kekurangan dan kesalahan yang telah diperbuat.

Pemberian balikan baik secara simbol maupun secara ekspositorik bertujuan agar memudahkan siswa untuk memperbaiki kesalahan yang telah diperbuatnya dan diprediksi dapat berpengaruh positif terhadap peningkatan kompetensinya.

\section{Kompetensi Mengatur Perjalanan Bisnis \\ 1. Kompetensi}

Pendapat tentang pengertian kompetensi banyak dikemukakan oleh beberapa pihak. Kompetensi merupakan perpaduan dari pengetahuan, keterampilan, nilai, dan sikap yang direfleksikan dalam kebiasaan berpikir dan bertindak. Kompetensi mencakup, keterampilan, sikap, dan apresiasi yang harus dimiliki oleh peserta didik untuk dapat melaksanakan tugas-tugas pembelajaran sesuai dengan jenis pekerjaan tertentu (Mulyasa, 2006:37-38). Menurut Prayitno (2014:283) kompetensi adalah kemampuan seseorang melakukan satuan kegiatan yang dapat segera diwujudkan untuk memenuhi keperluan tertentu. Secara terperinci Safary (2005:4) mengemukakan bahwa siswa dikatakan kompeten, apabila siswa mampu: (1) memahami konsep yang mendasari standar kompetensi yang harus dikuasai/ dicapai, (2) melakukan pekerjaan sesuai dengan tuntutan standar kompetensi yang harus dicapai dengan cara dan prosedur yang benar serta hasil yang baik, dan (3) mengaplikasikan kemampuannya dalam kehidupan sehari-hari. Dari tiga pendapat tersebut dapat disimpulkan bahwa yang dimaksud dengan kompetensi siswa adalah kemampuan siswa, baik secara teori maupun praktik untuk melakukan suatu pekerjaan pada standar kompetensi tertentu.

Kompetensi siswa dapat diukur atau diketahui dari beberapa perilaku yang ditunjukkan. Seseorang yang telah memiliki kompetensi dalam bidang tertentu bukan hanya mengetahui, akan tetapi juga dapat memahami dan menghayati bidang tersebut yang tercermin dalam pola perilaku seharihari (Sanjaya, 2008: 133). Menurut pendapat Safary (2005:3), pada prinsipnya di dalam kompetensi terdiri dari lima perilaku yang dapat diukur yaitu perilaku yang tersembunyi meliputi: (1) motif/latar belakang, 
(2) perlakuan, (3) sikap/nilai dan perilaku yang tampak meliputi: (4) pengetahuan (knowledge) dan (5) keterampilan. Selanjutnya diuraikan juga oleh Safary (2005:4) bahwa siswa dikatakan kompeten, apabila siswa mampu: (1) memahami konsep yang mendasari standar kompetensi yang harus dikuasai/dicapai, (2) melakukan pekerjaan sesuai dengan tuntutan standar kompetensi yang harus dicapai dengan cara dan prosedur yang benar serta hasil yang baik, dan (3) mengaplikasikan kemampuannya dalam kehidupan sehari-hari.

Baik buruknya kompetensi siswa, atau tercapai tidaknya kompetensi siswa, indikatornya dapat diketahui dari hasil pengukuran jenis perilaku siswa yang meliputi ranah kognitif, ranah afektif dan ranah psikomotoris. Menurut Sudjana (2006: 22) dalam Sistem Pendidikan nasional, rumusan tujuan pendidikan, baik tujuan kurikuler maupun tujuan instruksional, menggunakan klasifikasi hasil belajar dari Benyamin Bloom yang secara garis besar membaginya menjadi tiga ranah, yakni ranah kognitif, ranah afektif dan ranah psikomotoris.

Selanjutnya, Sudjana (2006: 22-23) menjelaskan bahwa yang dimaksud dengan ranah kognitif adalah berkenaan dengan hasil belajar intelektual yang terdiri dari enam aspek, yakni pengetahuan atau ingatan, pemahaman, aplikasi, analisis, sintesis dan evaluasi. Ranah afektif berkenaan dengan sikap yang terdiri dari lima aspek, yakni penerimaan, jawaban atau reaksi, penilaian, organisasi dan internalisasi. Ranah psikomotoris berkenaan dengan hasil belajar keterampilan dan kemampuan bertindak. Ada enam aspek yakni gerakan refleks, keterampilan gerakan dasar, kemampuan perseptual, keharmonisan dan ketepatan, gerakan keterampilan kompleks, dan gerakan ekspresif dan interpretatif.

\section{Standar Kompetensi Mengatur Perjalanan Bisnis}

Standar kompetensi Mengatur Perjalanan Bisnis adalah salah satu standar kompetensi pada Mata Pelajaran Kejuruan di Program Keahlian Administrasi Perkantoran SMK Negeri 1 Magetan yang dijabarkan dalam tiga kompetensi dasar, yaitu (1) merencanakan perjalanan bisnis, (2) mengatur perjalanan bisnis, dan (3) membuat laporan perjalanan bisnis.

Kompetensi dasar selanjutnya dijabarkan menjadi indikator. Indikator adalah karakteristik, ciri-ciri, tanda-tanda perbuatan/ respon yang harus dilakukan/ditampilkan oleh siswa untuk menunjukkan bahwa siswa telah menguasai kompetensi dasar (Depdiknas, 2003:9). Kompetensi dasar merencanakan perjalanan dinas memiliki 3 macam indikator yaitu: (1) perencanaan perjalanan telah dipersiapkan disesuaikan dengan keperluan-keperluan untuk pertemuan, kebutuhan-kebutuhan perjalanan, jaminan kesehatan dan kebutuhan keamanan untuk para pejalan, (2) kebutuhan dokumen perjalanan dan dokumen-dokumen untuk pertemuan telah ditujukan untuk para pejalan dengan waktu yang tepat, dan (3) persiapan perjalanan dan keperluan-keperluan untuk pertemuan telah dikonfirmasikan.

Kompetensi dasar Mengatur Perjalanan Bisnis memiliki 3 macam indikator yaitu: (1) pemesanan-pemesanan untuk keperluan perjalanan bisnis telah dibuat sesuai dengan ketentuan dan prosedur untuk perjalanan, (2) dokumen perjalanan telah diidentifikasi, diperiksa, disusun, dan telah dikirimkan kepada pejalan dengan tepat waktu, dan (3) penyusunan jadwal perjalanan telah dibuat dan dikonfirmasikan kepada pejalan.

Kompetensi Dasar Membuat Laporan Perjalanan Bisnis memiliki 2 indikator yaitu (1) pengaturan pembayaran dan cara-cara pembayaran telah diperiksa dan dikonfirmasikan dan dibuat sesuai dengan kebijakan 
dan prosedur organisasi dan (2) penyusunan laporan perjalanan bisnis telah dibuat sesuai dengan prosedur organisasi.

\section{Kompetensi Siswa dalam Mengatur Perjalanan Bisnis}

Siswa dinyatakan kompeten pada standar kompetensi Mengatur Perjalanan Bisnis jika siswa mencapai ketuntasan belajar untuk setiap bentuk penilaian yang dilakukan oleh guru pada setiap kompetensi dasar. Ketentuan ketuntasan tersebut adalah untuk ranah kognitif $\geq 75,00$, ranah afektif $\geq 75,00$ dan ranah psikomotoris $\geq 75,00$. Persentase untuk ranah kognitif : $30 \%$, ranah afektif : 20\% dan ranah psikomotoris : 50\%. Siswa dinyatakan tuntas belajar untuk ketiga ranah tersebut jika setelah dipersentase hasil penjumlahannya mencapai $>75,00$.

\section{METODE PENELITIAN}

\section{A. Rancangan Penelitian}

Penelitian ini direncanakan dalam dua siklus. Setiap siklusnya terdiri dari empat tahap yaitu:(1) perencanaan, (2) pelaksanaan, (3) pengamatan, dan (4) refleksi (Arikunto, 2007: 16). Dari data hasil refleksi siklus I akan dipergunakan sebagai acuan untuk menyusun perencanaan pada siklus II. Hal ini dimaksudkan untuk selalu mengadakan perbaikan pada setiap siklusnya sehingga tujuan dari penelitian ini dapat tercapai. Selanjutnya, diuraikan rancangan penelitian untuk setiap siklusnya sebagai berikut:

\section{Siklus I}

\section{a. Perencanaan}

Arikunto (2007:17) menyatakan dalam tahap perencanaan peneliti menjelaskan tentang apa, mengapa, kapan, di mana, oleh siapa, dan bagaimana tindakan tersebut dilakukan. Peneliti menentukan titik atau fokus peristiwa yang perlu mendapatkan perhatian khusus untuk diamati, kemudian membuat sebuah instrument pengamatan untuk membantu peneliti merekam fakta yang terjadi selama tindakan berlangsung. Tahap perencanaan merupakan persiapan dalam melakukan kegiatan penelitian.

Berdasarkan hal itu kegiatan pada tahap ini adalah: (1) menyusun silabus, (2) menyusun Rencana Pelaksanaan Pembelajaran (RPP) siklus I dengan menerapkan metode pemberian balikan dan materi pelajaran yang akan disajikan tentang menyusun jadwal kerjalagenda kegiatan pimpinan, (3) menyiapkan media pembelajaran, (4) membuat lembar kerja siswa berupa soal tugas menyusun agenda kegiatan pimpinan, (5) menyusun instrumen tes siklus I, dan (5) menyiapkan lembar pengamatan kegiatan pembelajaran.

\section{b. Pelaksanaan}

Menurut pendapat Arikunto (2007: 18) pelaksanaan tindakan ini berupa implementasi atau penerapan isi rancangan, yaitu mengenakan tindakan di kelas. Untuk itu pada tahap ini guru melaksanakan kegiatan pembelajaran di kelas sesuai dengan Rencana Pelaksanaan Pembelajaran (RPP) dengan waktu yang telah ditetapkan. Secara garis besar pada kegiatan inti pembelajaran, guru melakukan hal-hal sebagai berikut: (1) menjelaskan tujuan pembelajaran dan garis besar materi pelajaran dengan memberikan contoh cara menyusun jadwal kerja/ agenda kegiatan pimpinan, (2) membagikan lembar kerja kepada siswa berupa tugas untuk menyusun agenda kegiatan pimpinan, (3) mengoreksi tugas yang dikerjakan oleh siswa dengan pemberian balikan dengan cara memberikan simbol (B) untuk jawaban yang betul dan simbol (S) untuk jawaban yang salah, (4) membagikan tugas yang telah dikoreksi kepada siswa dan meminta siswa memperbaiki jika ada kesalahan dan menyerahkan kembali kepada guru untuk dikoreksi 
kembali sampai dinyatakan tugas tersebut betul, dan (5) memberi soal tes siklus I.

\section{c. Pengamatan}

Pengamatan dilakukan bersamaan dengan kegiatan pembelajaran berlangsung. Hal yang diamati adalah aktivitas guru dan siswa selama kegiatan pembelajaran. Pengamatan dilakukan dengan cara memberikan skor pada setiap aspek pengamatan yang terdapat pada lembar pengamatan. Selain itu pengamat juga memberikan catatan tentang hal-hal yang menjadi temuan di lapangan dengan tujuan melengkapi hasil pengamatan. Pada penelitian ini yang akan bertugas sebagai pengamat adalah teman sejawat yaitu Ibu Dra. Tutik Aminah.

\section{d. Refleksi}

Pada tahap ini hasil tes dan hasil pengamatan dianalisis untuk mengetahui letak keberhasilan dan hambatan dari tindakan yang telah dilakukan. Hal-hal yang positif yang mendukung keberhasilan pelaksanaan metode pemberian balikan pada siklus I dipertahankan dan hal yang negatif diperbaiki. Hasil evaluasi yang diperoleh dijadikan dasar untuk melakukan refleksi untuk memperbaiki tindakan yang akan dilaksanakan pada siklus II.

\section{Siklus II}

\section{a. Perencanaan}

Pada tahap perencanaan siklus II ini, hal-hal yang dilakukan adalah:

(1) menyusun perbaikan Rencana Pelaksanaan Pembelajaran (RPP) berdasarkan hasil refleksi pada siklus I dengan materi pelajaran menyusun jadwal perjalanan dinas pimpinan, (2) membuat media pembelajaran, (3) membuat lembar kerja siswa berupa soal tugas menyusun jadwal perjalanan dinas pimpinan, (4) menyusun instrumen tes siklus II, dan (5) lembar pengamatan kegiatan pembelajaran.

\section{b. Pelaksanaan}

Pada tahap tindakan siklus II guru menerapkan Rencana Pelaksanaan Pembelajaran (RPP) siklus II yang merupakan penyempurnaan dari RPP siklus I. Guru mempertahankan hal-hal yang positif yang dilakukan pada siklus I dan berusaha memperbaiki kekurangan yang terjadi pada siklus I.

\section{c. Pengamatan}

Pengamatan dilakukan secara cermat terhadap setiap aktivitas siswa dan guru selama kegiatan pembelajaran. Caranya adalah pengamat memberikan skor pada setiap aspek pengamatan yang terdapat pada lembar observasi dan mencatat halhal yang menjadi temuan selama kegiatan belajar mengajar dengan tujuan melengkapi hasil pengamatan.

\section{d. Refleksi}

Hasil tes dan pengamatan pada siklus II dianalisis dengan tujuan untuk mengetahui letak keberhasilan dan kekurangan dari tindakan yang telah dilakukan. Halhal yang positif dipertahankan dan hal-hal yang negatif dibenahi dan diperbaiki. Setelah itu dilakukan evaluasi dan hasilnya dijadikan sebagai dasar untuk melakukan refleksi untuk mengungkapkan tingkat keberhasilan tindakan pada siklus II dan kekurangan yang mungkin masih terjadi.

\section{B. Subyek dan Setting Penelitian}

Subyek penelitian ini adalah siswa kelas XII Program Keahlian Administrasi Perkantoran-2 (XII APk-2) semester ganjil tahun pelajaran 2014/2015 di SMK Negeri 1 Magetan, yang beralamat di Jalan Kartini No. 6 Magetan, Telp/Fax (0351-895094). Jumlah siswa di kelas XII APk-2 sebanyak 40 siswa yang terdiri dari 38 siswa perempuan dan 2 siswa laki-laki.

Alasan penelitian ini dikenakan pada kelas tersebut adalah pada saat mereka 
mengikuti kegiatan pembelajaran Standar Kompetensi Mengatur Perjalanan Bisnis dengan Kompetensi Dasar Mengatur Perjalanan Bisnis, siswa kurang aktif dan pencapaian kompetensi siswa tergolong rendah. Hal ini diketahui dari data hasil pengamatan dan data hasil tes yang dilakukan sebelum tindakan. Berdasarkan data hasil pengamatan menunjukkan bahwa siswa kurang bersungguh-sungguh dalam mengerjakan latihan atau tugas, banyak melakukan kesalahan, mengumpulkan tugas tidak tepat waktu, dan kurang memperhatikan kebersihan dan kerapian, sedangkan data hasil tes menunjukkan bahwa nilai rerata kelas rendah dan ketuntasan belajar secara klasikal belum tercapai. Hal ini berarti pencapaian kompetensi siswa tergolong masih rendah.

Penelitian ini dilakukan oleh penulis yang berstatus sebagai guru mata pelajaran kejuruan di Program Keahlian Administrasi Perkantoran SMK Negeri 1 Magetan. Peneliti dibantu oleh teman sejawat yang bertugas sebagai pengamat yaitu Dra. Tutik Aminah yang juga berstatus sebagai guru mata pelajaran kejuruan di Program Keahlian Administrasi Perkantoran SMK Negeri 1 Magetan.

\section{Teknik dan Instrumen Pengumpulan Data}

Teknik pengumpulan data yang digunakan dalam penelitian ini adalah tes dan nontes. Sedangkan instrumen pengumpulan datanya berupa soal tes buatan guru dan lembar pengamatan aktivitas pembelajaran.

\section{Tes}

Tes digunakan untuk mengumpulkan data hasil hasil pencapaian kompetensi siswa setelah mengikuti pembelajaran dengan penerapan metode Pemberian Balikan. Tes dalam penelitian ini berupa tes tulis dan tes kinerja. Kompetensi siswa yang dimaksud adalah kompetensi yang meliputi ranah kognitif, ranah afektif dan ranah psikomotoris.

\section{a. Tes Kompetensi Ranah Kognitif}

Tes kompetensi ranah Kognitif dilakukan di akhir siklus. Bentuk tes untuk menilai ranah kognitif pada siklus I dan siklus II adalah uraian tertulis. Jumlah soal pada setiap siklus terdiri dari 2 soal dengan 5 aspek penilaian. Skor penilaian diberikan dengan ketentuan skor 0 jika siswa tidak menjawab, skor 1 jika siswa menjawab tapi jawabannya salah, skor 2 jika jawaban siswa sebagian besar salah, skor 3 jika jawaban siswa sebagian besar betul, dan skor 4 jika jawaban siswa betul. Skor maksimal 20. Nilai siswa diperoleh dari pembagian skor yang diperoleh dengan skor maksimal dan hasilnya dikalikan dengan 100.

Ketuntasan belajar tercapai jika siswa memperoleh nilai $\geq 75$. Besarnya persentase nilai ranah kognitif untuk menentukan nilai akhir adalah $30 \%$.

\section{b. Tes Kompetensi Ranah Afektif}

Tes kompetensi ranah afektif dilakukan selama kegiatan pembelajaran berlangsung. Penilaian dengan menggunakan rubrik penilaian menyusun agenda kegiatan pimpinan pada siklus I dan rubrik penilaian menyusun jadwal perjalanan dinas pada siklus II. Aspek penilaian terdiri dari 5 aspek yaitu aspek kejujuran, aspek kedisiplinan, aspek tanggung jawab, aspek kemandirian, dan aspek ketekunan. Skor penilaian diberikan dengan ketentuan skor 1 jika siswa melakukan dengan sangat tidak baik, skor 2 jika siswa melakukan dengan tidak baik, skor 3 jika siswa melakukan dengan kurang baik, skor 4 jika siswa melakukan dengan baik dan skor 5 jika siswa melakukan dengan sangat tidak baik. Skor maksimal 25. Nilai siswa diperoleh dari pembagian skor yang diperoleh dengan skor maksimal dan hasilnya dikalikan dengan 100. 
Ketuntasan belajar tercapai jika siswa memperoleh nilai $\geq 75$. Besarnya persentase nilai ranah Afektif untuk menentukan nilai akhir adalah $20 \%$.

\section{c. Tes Kompetensi Ranah Psikomotoris}

Tes kompetensi ranah psikomotoris dilakukan di akhir siklus. Bentuk tes untuk menilai ranah psikomotoris adalah tes praktik menyusun agenda kegiatan pimpinan pada siklus I dan menyusun jadwal perjalanan dinas pada siklus II dengan masing-masing terdiri dari 10 aspek penilaian. Skor penilaian diberikan dengan ketentuan skor 0 jika siswa tidak mengerjakan, skor 1 jika siswa mengerjakan tapi tidak benar, skor 2 jika pekerjaan siswa kurang lengkap dan benar, skor 3 jika pekerjaan siswa lengkap dan benar, dan skor 4 jika pekerjaan siswa sangat lengkap dan benar. Skor maksimal 40 . Nilai siswa dipeoleh dari pembagian skor yang diperoleh dengan skor maksimal dan hasilnya dikalikan dengan 100. Ketuntasan belajar tercapai jika siswa memperoleh nilai $\geq 75$. Besarnya persentase nilai ranah psikomotoris untuk menentukan nilai akhir adalah 50\%.

\section{Nontes}

Instrumen nontes yang digunakan dalam penelitian ini berupa lembar pengamatan kegiatan pembelajaran. Pengamatan dilakukan terhadap aktivitas guru dan siswa, waktunya bersamaan dengan berlangsungnya kegiatan pembelajaran dengan menerapkan metode pemberian balikan pada siklus I dan siklus II. Sambil melakukan pengamatan, pengamat mencatat terhadap apa yang terjadi untuk mendapatkan data yang akurat untuk memperbaiki siklus berikutnya (Arikunto, 2007: 19).

Pengamatan terhadap aktivitas siswa dalam penelitian ini terdiri dari 8 aspek pengamatan. Pengamat memberikan tanda $(\sqrt{ })$ untuk memberikan skor pada setiap aspek. Sedangkan pengamatan untuk aktivitas guru dilakukan dengan cara mengisi catatan lapangan yang disediakan. Lembar pengamatan seperti pada tabel berikut ini:

Tabel 3.1 Lembar Pengamatan Kegiatan Pembelajaran

\begin{tabular}{|c|c|c|c|c|c|}
\hline \multirow{2}{*}{ No. } & \multirow{2}{*}{ Aktivitas Siswa yang diamati } & \multicolumn{4}{|c|}{ Skor } \\
\hline & & 1 & 2 & 3 & 4 \\
\hline 1 & Mendengarkan/memperhatikan penjelasan guru & & & & \\
\hline 2 & Aktif bertanya, menjawab dan berpendapat / berkomentar & & & & \\
\hline 3 & Membuat catatan penting materi pelajaran & & & & \\
\hline 4 & Bersungguh-sungguh dalam mengerjakan tugas & & & & \\
\hline 5 & Mandiri dalam mengerjakan tugas & & & & \\
\hline 6 & Mengumpulkan tugas tepat waktu & & & & \\
\hline 7 & Mampu merefleksi hasil tugas yang dikerjakan & & & & \\
\hline 8 & Antusias dalam kegiatan pembelajaran & & & & \\
\hline & JUMLAH & & & & \\
\hline
\end{tabular}

Petunjuk pengisian:

(*) Berikan tanda check list $(\sqrt{ })$ pada jawaban Anda

Keterangan:

Nilai Kriteria

$4 \geq$ Amat baik

$3 \geq$ Baik

$2 \geq$ Kurang

$1 \geq$ Amat Kurang

Catatan Lapangan: 
D. Teknik Analisis Data

Pengolahan terhadap data yang terkumpul pada penelitian ini bertujuan menghasilkan suatu kesimpulan yang dapat dipertanggungjawabkan. Teknik analisis data yang digunakan dengan cara analisis data kuantitatif pada hasil tes yang dikerjakan siswa dan analisis data kualitatif pada hasil pengamatan kegiatan pembelajaran.

\section{Data Hasil Tes}

Analisis data untuk hasil tes digunakan rumus sebagai berikut:

\section{a. Nilai Rerata Kelas}

$\bar{X}=\frac{\sum X}{N}$

$\bar{X} \geq$ Nilai rerata

$\sum X \geq$ Jumlah nilai seluruh siswa

$N \geq$ Banyaknya siswa yang ikut tes (Sudjana, 2002:67)

b. Nilai Individu untuk Ranah Kognitif, Afektif dan Psikomotoris

Nilai Individu $\geq \frac{\text { Jumlah skor yang diperoleh siswa }}{\text { Jumlah skor maksimal }} \times 100$

(Slameto, 2001:189)

\section{c. Nilai akhir Individu}

Nilai akhir individu dihitung dengan cara:

$(30 \%$ nilai Kognitif $+20 \%$ nilai afektif $+50 \%$ nilai Kognitif $)$

\section{d. Rumus Menghitung Persentase Ketuntasan Belajar Individu}

$\% \geq \frac{\mathrm{n}}{\mathrm{N}} \times 100 \%$

Keterangan:

$\% \geq$ Persentase

$\mathrm{n} \geq$ Jumlah skor yang diperoleh siswa

$\mathrm{N} \geq$ Jumlah skor maksimal (Ali, 1993:186)

Siswa dinyatakan tuntas belajar atau kompeten jika memperoleh nilai $\geq 75,00$ atau dengan persentase $\geq 75 \%$.

e. Rumus Menghitung Persentase Ketuntasan Belajar Klasikal

$\% \geq \frac{\mathrm{n}}{\mathrm{N}} \times 100 \%$

Keterangan:

$\% \geq$ Persentase

$\mathrm{n} \geq$ Jumlah siswa yang tuntas belajar

$\mathrm{N} \geq$ Jumlah seluruh siswa yang mengikuti tes (Ali, 1993:186) 
Ketuntasan belajar secara klasikal ditentukan dengan jumlah siswa yang tuntas. Secara individual $\geq 85 \%$ dari seluruh jumlah siswa yang mengikuti tes.

\section{Data Hasil Pengamatan}

Pengambilan data melalui pengamatan dilakukan dengan cara memberi skor untuk setiap aspek dengan menggunakan skala likert dengan rentang 4 sampai dengan 1. Jika dalam penelitian ini terdapat 8 aspek yang harus diamati, maka skor maksimumnya adalah 32. Apabila dalam penelitian aktivitas siswa dibagi dalam empat kategori maka aktivitas siswa dengan skor :

$$
\begin{aligned}
25-32 & \geq \text { Amat Baik } \\
17-24 & \geq \text { Baik } \\
9-16 & \geq \text { Kurang } \\
<8 & \geq \text { Amat kurang }
\end{aligned}
$$

(Priatiningsih, 2004:13)

Rumus untuk menghitung nilai aktivitas siswa adalah:

$$
\text { Nilai Aktivitas Siswa } \geq \frac{\text { Jumlah skor yang diperoleh }}{\text { Jumlah skor maksimal }} \times 100
$$

Sedangkan untuk aktivitas guru, pengamat cukup memberikan catatan tentang hal-hal yang sudah baik yang dilakukan oleh guru dan hal-hal yang perlu diperbaiki.

\section{E. Indikator Kinerja}

Indikator keberhasilan yang ditetapkan dalam penelitian ini adalah:

1. Pencapaian kompetensi siswa ditunjukkan dengan nilai akhir yang diperoleh dari penjumlahan nilai ranah kognitif, nilai ranah afektif dan nilai ranah psikomotoris dengan ketentuan $30 \%$ nilai ranah kognitif, 20\% nilai ranah afektif dan 50\% nilai ranah psikomotoris. Hasilnya adalah siswa dikatakan kompeten atau tuntas belajar jika nilai yang diperoleh mencapai $\geq 75$ atau dengan persentase $\geq 75 \%$. Pencapaian kompetensi siswa secara klasikal ditunjukkan dengan jumlah siswa yang kompeten atau mencapai ketuntasan belajar secara individu mencapai $\geq 85 \%$ dari jumlah siswa.

2. Aktivitas siswa dibagi dalam empat kategori. Aktivitas siswa dengan skor:

$$
\begin{aligned}
25-32 & \geq \text { Amat baik } \\
17-24 & \geq \text { Baik } \\
9-16 & \geq \text { Kurang } \\
<8 & \geq \text { Amat kurang }
\end{aligned}
$$

\section{F. Jadwal Penelitian}

Penelitian dilaksanakan pada bulan Juli sampai dengan bulan September tahun 2014 pada semester ganjil tahun pelajaran 2014/2015 dengan jadwal penelitian sebagai berikut:

\section{HASIL DAN PEMBAHASAN}

\section{A. Deskripsi Situasi dan Kondisi Tempat Penelitian}

Penelitian ini dilakukan di Program Keahlian Administrasi Perkantoran SMK Negeri 1 Magetan, yaitu di kelas XII Administrasi Perkantoran-2 (XII APk-2) pada semester ganjil tahun pelajaran 2014/2015 dengan jumlah 40 siswa. Siswa laki-laki sebanyak 2 orang dan siswa perempuan sebanyak 38 orang. Sekitar 90\% domisili siswa berada di luar kecamatan Magetan, yang berjarak sekitar $7 \mathrm{~km}$ hingga $15 \mathrm{~km}$ dari sekolah. Siswa ke sekolah dengan berjalan kaki, diantar orang tua, naik angkutan umum atau naik sepeda motor. Tingkat perekonomian orang tua siswa termasuk kelas menengah ke bawah.

Kondisi kelas XII APk-2 cukup representatif, bersih, perabot dan peralatan kelas cukup lengkap. Letak kelas berada di sebelah Selatan paling Barat dari gedung sekolah, di antara kelas XII APk-1 dan kelas XII APk-3 
menghadap ke Utara berhadapan dengan kelas XII PMS-1, XII PMS-2 dan XII PMS-3.

Kompetensi siswa kelas XII APk-2 yang ditunjukkan dengan nilai hasil belajarnya masih tergolong rendah. Dari data hasil tes sebelum tindakan yang dilakukan diketahui bahwa: (a) nilai tertinggi sebesar 80.45 , (b) nilai terendah sebesar 66.65, (c) nilai rerata kelas sebesar 74.78, dan (d) ketuntasan belajar secara klasikal sebesar $55 \%$. Selain itu dari data hasil pengamatan terhadap aktivitas siswa, diperoleh skor sebesar 10 dengan kategori "kurang".

Pencapaian kompetensi siswa yang rendah dan siswa kurang aktif dalam kegiatan pembelajaran tersebut, salah satu penyebabnya adalah guru tidak mengelola kegiatan pembelajarannya dengan baik, khususnya dalam hal pemberian penilaian. Penilaian berupa tes, latihan atau tugas yang diberikan oleh guru masih belum berdampak positif bagi pencapaian kompetensi siswa juga peningkatannya. Misalnya frekuensi pemberian tes, latihan atau tugas yang kurang, tes, latihan atau tugas yang terlalu sulit untuk dikerjakan, tidak ada kriteria penilaian dan batas waktu yang jelas, tidak ada umpan balik, dan tak jarang pula dijumpai guru tidak mengoreksi hasil tes, latihan atau tugas yang dikerjakan oleh siswa. Kadang guru hanya menyalahkan hasil tugas yang dikerjakan oleh siswa tanpa memberi informasi bagaimana memperbaiki kesalahan tersebut. Hal ini menyebabkan siswa tidak mengerjakan tugas dengan sungguh-sungguh, banyak kesalahan, kurang memperhatikan kerapian dan kebersihan, kurang mandiri dalam mengerjakan, atau kadang ditemui pula beberapa siswa yang tidak mengerjakan. Akibatnya adalah pencapaian kompetensi siswa rendah sehingga perlu diterapkan suatu metode pembelajaran yang dapat mengatasi permasalahan tersebut.

\section{B. Hasil Penelitian Siklus I \\ 1. Perencanaan}

Kegiatan perencanaan siklus I dilaksanakan pada minggu pertama bulan Agustus tahun 2014, yaitu dimulai dari tanggal 4 Agustus sampai dengan tanggal 9 Agustus tahun 2014. Pada tahap ini kegiatan diawali dengan menyusun silabus. Berdasarkan silabus Rencana Pelaksanaan Pembelajaran (RPP) siklus I disusun dengan menggunakan metode pemberian balikan. Kegiatan pembelajaran siklus I akan dilaksanakan dalam satu kali pertemuan sebanyak 4 jam pelajaran sesuai dengan jadwal pelajaran. Durasi waktu pembelajaran sebanyak 180 menit. Materi pelajaran yang disajikan tentang pengaturan jadwal kerja/agenda kegiatan pimpinan. Indikator keberhasilan yang ditetapkan adalah penyusunan jadwal kerja/agenda kegiatan pimpinan telah dibuat sesuai dengan prosedur organisasi. Untuk memperjelas penyampaian materi pelajaran, pada tahap ini juga disiapkan media berupa media gambar macam-macam dokumen yang dibuat dalam bentuk power point.

Selanjutnya disusun pula lembar kerja siswa berupa tugas individu untuk membuat jadwal kerja/agenda kegiatan pimpinan. Hasilnya akan dikoreksi dengan menggunakan metode pemberian balikan dengan memberikan simbol (B) untuk jawaban yang benar dan simbol (S) untuk jawaban yang salah. Kemudian disusun instrument tes siklus I yang terdiri dari kisi-kisi, soal, kunci jawaban, pedoman penskoran, rumus penghitungan nilai siswa dan lembar penilaian. Tes siklus I ini bertujuan untuk mengetahui pencapaian kompetensi siswa atau nilai siswa pada ranah kognitif, ranah afektif dan ranah psikomotoris. Nilai akhir siswa diperoleh dari penjumlahan nilai ketiga ranah tersebut setelah masing-masing ranah dipersentase dengan ketentuan 30\% untuk ranah kognitif, $20 \%$ untuk ranah afektif, dan 50\% untuk ranah psikomotoris. Siswa dinyatakan tuntas 
belajar atau kompeten jika nilai akhir yang diperoleh $\geq 75$. Ketuntasan belajar secara klasikal ditetapkan jika jumlah siswa yang tuntas belajar (kompeten) $\geq 85 \%$ dari jumlah siswa yang mengikuti tes.

Pengamatan terhadap aktivitas siswa dan guru selama kegiatan pembelajaran disediakan lembar pengamatan yang disajikan dalam bentuk table pengamatan dan catatan lapangan. Tabel pengamatan berisi 8 aspek pengamatan terhadap aktivitas siswa. Pengamat mengisikan skor untuk setiap aspek dengan cara memberi tanda $(\sqrt{ })$ pada skor yang dipilih. Catatan lapangan untuk mencatat aktivitas guru selama kegiatan pembelajaran. Pengamat mencatat hal-hal yang dianggap sudah baik atau hal-hal yang perlu diperbaiki.

\section{Pelaksanaan}

Kegiatan belajar mengajar siklus I dilaksanakan pada hari Senin tanggal 11 Agustus 2014 di kelas XII APk-2. Kegiatan pembelajaran berlangsung sesuai jadwal pelajaran yaitu dimulai dari jam ke- 3 sampai dengan jam ke-6 atau selama 4 jam pembelajaran untuk satu kali tatap muka. Durasi waktu pembelajaran selama 180 menit. Di sini peneliti bertindak sebagai guru dan Ibu Dra. Tutik Aminah sebagai pengamat. Kegiatan belajar mengajar mengacu pada rencana pelaksanaan pembelajaran yang telah disiapkan. Pada hari itu siswa hadir sejumlah 40 siswa.

Di awal penyajian materi pelajaran, guru menampilkan gambar contoh jenis-jenis dokumen melalui power point dan menanyakan kepada siswa nama-nama dari dokumen tersebut. Guru ingin mengetahui apakah siswa telah memahami materi pelajaran pada pertemuan minggu lalu yang membahas tentang jenis-jenis dokumen perjalanan dinas. Hal ini dimaksudkan agar siswa mempunyai alur berpikir yang berkesinambungan karena materi pelajaran yang akan diterima pada hari ini berhubungan dengan materi pelajaran yang diterima pada minggu lalu. Pada saat itu siswa menjawab secara bersahut-sahutan tetapi tidak berani mengangkat tangannya.

Guru meminta kepada siswa untuk mengangkat tangannya terlebih dahulu sebelum menjawab. Kebanyakan mereka tampak ragu-ragu dan tidak berani tetapi ada beberapa siswa yang memberanikan diri menjawab dengan terlebih dahulu mengangkat tangannya. Secara bergantian mereka ditunjuk untuk menjawab. Ternyata dari 10 siswa yang menjawab, 6 orang menjawab dengan benar dan 4 orang menjawab dengan jawaban yang salah. Mengetahui kondisi tersebut, guru meminta siswa untuk membaca kembali buku modul dan menghafal materi tentang jenis-jenis dokumen perjalanan dinas di rumah.

Selanjutnya guru menjelaskan garis besar materi pelajaran tentang pengaturan jadwal kerja/agenda kegiatan pimpinan dan memberi contoh cara membuat jadwal kerja/ agenda kegiatan pimpinan. Kemudian guru membagikan lembar kerja siswa berupa soal tugas menyusun agenda kegiatan pimpinan. Selama siswa mengerjakan, guru mengamati kegiatan siswa. Pada waktu yang telah ditentukan, siswa mengumpulkan hasil pekerjaannya kepada guru untuk dikoreksi. Guru memberikan simbol (B) pada jawaban yang betul dan simbol (S) pada jawaban yang salah. Setelah semua jawaban dikoreksi, guru mengembalikannya ke siswa. Siswa yang diminta memperbaiki tugasnya karena ada kesalahan sebanyak 12 siswa. Pada saat siswa memperbaiki tugasnya, beberapa siswa menanyakan bagaimana cara membetulkannya karena kurang mengerti, sehingga guru harus menjelaskan kepada mereka. Meskipun siswa sudah memperbaiki kesalahannya, tetapi ketika dikoreksi kembali, masih ada 3 orang siswa yaitu Ita, Noviana, dan Parsitasari yang masih melakukan kesalahan dan harus memperbaiki. Setelah guru mengoreksinya lagi, ketiga siswa itu telah mengerjakan tugasnya dengan betul. 
Di akhir kegiatan inti, guru memberikan tes siklus I. Tes ini dilakukan untuk memperoleh data nilai siswa untuk ranah kognitif dan ranah psikomotoris.

Sedangkan untuk penilaian ranah afektif dilakukan selama kegiatan pembelajaran berlangsung.

Setelah menyimpulkan materi pelajaran bersama dengan siswa, guru memberikan tugas kepada siswa untuk mengetik tugas yang tadi dikerjakan dengan komputer dan menyerahkannya minggu depan. Guru menutup pelajaran dengan mengucapkan salam.

\section{Pengamatan}

Kegiatan pengamatan dilakukan bersamaan dengan pelaksanaan kegiatan pembelajaran oleh Ibu Dra. Tutik Aminah. Hasil pengamatan terhadap kegiatan pembelajaran pada siklus I tampak pada tabel 4.1.

Tabel 4.1 Hasil Pengamatan Kegiatan Pembelajaran Siklus I

\begin{tabular}{|c|c|c|c|c|c|}
\hline \multirow{2}{*}{ No. } & \multirow{2}{*}{ Aktivitas Siswa yang diamati } & \multicolumn{4}{|c|}{ Skor } \\
\hline & & 1 & 2 & 3 & 4 \\
\hline 1. & Mendengarkan / memperhatikan penjelasan guru & & & $\sqrt{ }$ & \\
\hline 2. & Aktif bertanya, menjawab dan berpendapat / berkomentar & & $\sqrt{ }$ & & \\
\hline 3. & Membuat catatan penting materi pelajaran & & & $\sqrt{ }$ & \\
\hline 4. & Bersungguh-sungguh dalam mengerjakan tugas & & $\sqrt{ }$ & & \\
\hline 5. & Mandiri dalam mengerjakan tugas & & $\sqrt{ }$ & & \\
\hline 6. & Mengumpulkan tugas tepat waktu & & $\sqrt{ }$ & & \\
\hline 7. & Mampu merefleksi hasil tugas yang dikerjakan & $\sqrt{ }$ & & & \\
\hline 8. & Antusias dalam kegiatan pembelajaran & & & $\checkmark$ & \\
\hline & JUMLAH & 1 & 8 & 9 & \\
\hline
\end{tabular}

Berdasarkan data tersebut diketahui bahwa aspek mendengarkan/memperhatikan penjelasan guru memperoleh skor 3, aspek aktif bertanya, menjawab dan berpendapat/ berkomentar memperoleh skor 2, aspek membuat catatan penting materi pelajaran memperoleh skor 3, aspek bersungguh-sungguh dalam mengerjakan tugas memperoleh skor 2, aspek mandiri dalam mengerjakan tugas memperoleh skor 2, aspek mengumpulkan tugas tepat waktu memperoleh skor 2, aspek mampu merefleksi hasil tugas yang dikerjakan memperoleh skor 1, dan aspek antusias dalam kegiatan pembelajaran memperoleh skor 3. Jadi jumlah skor yang diperoleh dari hasil pengamatan pada siklus I adalah 18 . Kategori untuk aktivitas siswa dengan skor 18 adalah "baik".

Catatan lapangan pada siklus I menyatakan bahwa meskipun guru telah melakukan hal-hal yang positip yaitu sudah menggunakan media pembelajaran yang menarik dan guru telah menjelaskan materi pembelajaran dengan baik, tetapi guru juga melakukan hal-hal yang kurang mendukung keberhasilan penerapan metode pemberian balikan. Misalnya, (a) situasi kelas ramai karena saat guru mengoreksi tugas, siswa tidak diberi kegiatan oleh guru, (b) pemberian balikan dengan cara memberikan simbol (B) pada jawaban yang betul dan simbol ( $\mathrm{S}$ ) pada jawaban yang salah membuat siswa tidak mengetahui bagaimana cara memperbaiki pekerjaannya, sehingga guru harus menjelaskan kembali untuk setiap siswa, dan (c) skenario pembelajaran selesai sebelum waktu berakhir sehingga menyebabkan kelas menjadi gaduh dan beberapa siswa mengajukan usul untuk istirahat lebih awal. Hal ini justru tidak mendidik kedisiplinan siswa.

\section{Data Hasil Tes Siklus 1}

Hasil tes siklus I dianalisis dan ditampilkan dalam tabel 4.2. 
Tabel 4.2 Data Hasil Tes Siklus I

\begin{tabular}{|c|c|c|c|c|c|c|c|c|c|}
\hline \multirow[t]{2}{*}{ No } & \multirow{2}{*}{$\begin{array}{ll}\text { Nama Siswa } & \text { Aspek Nilai }\end{array}$} & \multicolumn{2}{|c|}{ Kognitif } & \multicolumn{2}{|c|}{ Afektif } & \multicolumn{2}{|c|}{ Psikomotoris } & \multirow{2}{*}{$\begin{array}{c}\text { NILAI } \\
\text { AKHIR }\end{array}$} & Ketuntasan \\
\hline & & Nilai & $30 \%$ & Nilai & $20 \%$ & Nilai & $50 \%$ & & Ya Tidak \\
\hline 1. & FITRI NURUL KOTIMAH & 85 & 25.5 & 80 & 16 & 82.5 & 41.25 & 82.75 & $\checkmark$ \\
\hline 2. & FITRIA SARI & 75 & 22.5 & 76 & 15.2 & 77.5 & 38.75 & 76.45 & \\
\hline 3. & HENY TRI ERNAWATI & 80 & 24 & 80 & 16 & 90 & 45 & 85 & \\
\hline 4. & IDA ROSITA & 75 & 22.5 & 80 & 16 & 77.5 & 38.75 & 77.25 & $\sqrt{ }$ \\
\hline 5. & INDAH DWI ANISA & 70 & 21 & 76 & 15.2 & 67.5 & 33.75 & 69.95 & $\sqrt{ }$ \\
\hline 6. & INDRI ERNAWATI & 75 & 22.5 & 76 & 15.2 & 65 & 32.5 & 70.2 & $\sqrt{ }$ \\
\hline 7. & INTAN ARUMNINGTYAS & 75 & 22.5 & 80 & 16 & 77.5 & 38.75 & 77.25 & $v$ \\
\hline 8. & INTAN PERMATA SARI & 75 & 22.5 & 76 & 15.2 & 62.5 & 31.25 & 68.95 & $\sqrt{ }$ \\
\hline 9. & IRWAN SYAFI'IE & 80 & 24 & 76 & 15.2 & 80 & 40 & 79.2 & \\
\hline 10 & JULIANI & 75 & 22.5 & 80 & 16 & 75 & 37.5 & 76 & \\
\hline 11 & KARTIKA SEKAR HARUM & 85 & 25.5 & 80 & 16 & 77.5 & 38.75 & 80.25 & \\
\hline 12 & KHARISMA DIENNA SAKHOFI & 85 & 25.5 & 80 & 16 & 77.5 & 38.75 & 80.25 & \\
\hline 13 & KIKI PANGESTU & 70 & 21 & 72 & 14.4 & 67.5 & 33.75 & 69.15 & $\sqrt{ }$ \\
\hline 14 & KRISTYA NINGRUM & 75 & 22.5 & 80 & 16 & 77.5 & 38.75 & 77.25 & \\
\hline 15 & LILIS SURYANI & 75 & 22.5 & 80 & 16 & 90 & 45 & 83.5 & \\
\hline 16 & LINDA EKA UMMI K. & 75 & 22.5 & 76 & 15.2 & 77.5 & 38.75 & 76.45 & \\
\hline 17 & LINDA ROHAYATI & 80 & 24 & 80 & 16 & 77.5 & 38.75 & 78.75 & \\
\hline 18 & LUCKY ANANTA PRIBADI & 75 & 22.5 & 76 & 15.2 & 75 & 37.5 & 75.2 & $\sqrt{ }$ \\
\hline 19 & LUSI SETIANINGSIH & 85 & 25.5 & 92 & 18.4 & 80 & 40 & 83.9 & $\sqrt{ }$ \\
\hline 20 & LUSIANA DEWI ERMALA & 75 & 22.5 & 76 & 15.2 & 67.5 & 33.75 & 71.45 & $\sqrt{ }$ \\
\hline 21 & MARATUS SHOLIKAH & 75 & 22.5 & 80 & 16 & 77.5 & 38.75 & 77.25 & \\
\hline 22 & MARATUS SHOLIKAH & 70 & 21 & 76 & 15.2 & 80 & 40 & 76.2 & \\
\hline 23 & MEGA FEBRIANI & 75 & 22.5 & 76 & 15.2 & 62.5 & 31.25 & 68.95 & $\sqrt{ }$ \\
\hline 24 & MIA SURYA DEWI & 75 & 22.5 & 76 & 15.2 & 77.5 & 38.75 & 76.45 & \\
\hline 25 & NADIA ROHAGIA SUWITO P . & 85 & 25.5 & 76 & 15.2 & 85 & 42.5 & 83.2 & \\
\hline 26 & NANCY PUTRI UTAMI & 85 & 25.5 & 80 & 16 & 82.5 & 41.25 & 82.75 & 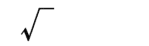 \\
\hline 27 & NI'MA NASIH & 70 & 21 & 76 & 15.2 & 62.5 & 31.25 & 67.45 & $\sqrt{ }$ \\
\hline 28 & NIMAS AYU NUR ZAKIYYAH & 80 & 24 & 76 & 15.2 & 82.5 & 41.25 & 80.45 & 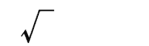 \\
\hline 29 & NITA AYU MAWARNI & 70 & 21 & 84 & 16.8 & 62.5 & 31.25 & 69.05 & $\sqrt{ }$ \\
\hline 30 & NITA KRISTIANA & 85 & 25.5 & 84 & 16.8 & 72.5 & 36.25 & 78.55 & $\sqrt{ }$ \\
\hline 31 & NITA PRASETYANI & 85 & 25.5 & 76 & 15.2 & 77.5 & 38.75 & 79.45 & $\sqrt{ }$ \\
\hline 32 & NOVI ANDRIANI & 80 & 24 & 76 & 15.2 & 87.5 & 43.75 & 82.95 & $\sqrt{ }$ \\
\hline 33 & NOVIA FAMILA ISTI & 85 & 25.5 & 80 & 16 & 70 & 35 & 76.5 & $\sqrt{ }$ \\
\hline 34 & NOVIANA ANDRIYANI & 85 & 25.5 & 80 & 16 & 77.5 & 38.75 & 80.25 & $\checkmark$ \\
\hline 35 & NOVITA & 85 & 25.5 & 84 & 16.8 & 77.5 & 38.75 & 81.05 & \\
\hline 36 & NOVITA ANDIKASARI & 75 & 22.5 & 84 & 16.8 & 72.5 & 36.25 & 75.55 & \\
\hline 37 & NUR LELAH & 85 & 25.5 & 80 & 16 & 85 & 42.5 & 84 & $\sqrt{ }$ \\
\hline 38 & NURUL HIDAYATI & 85 & 25.5 & 80 & 16 & 77.5 & 38.75 & 80.25 & . \\
\hline 39 & PRIMA AYU NURIZKA & 85 & 25.5 & 76 & 15.2 & 77.5 & 38.75 & 79.45 & 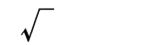 \\
\hline 40 & PRISKA ARINANDA YUNI F. & 85 & 25.5 & 76 & 15.2 & 85 & 42.5 & 83.2 & $\sqrt{ }$ \\
\hline & Jumlah & & & & & & & 3102.1 & \\
\hline
\end{tabular}

Berdasarkan data di atas, dari nilai akhir siswa diketahui bahwa nilai tertinggi sebesar 83.90, nilai terendah sebesar 67.45 , nilai rerata kelas sebesar 77,55 dan hasil penghitungan untuk ketuntasan belajar klasikal mencapai $80 \%$.

\section{Refleksi}

Berdasarkan data hasil pengamatan pada saat kegiatan pembelajaran dengan menerapkan metode pemberian balikan pada siklus I, secara garis besar dapat dikatakan bahwa aktivitas siswa tergolong baik. Tetapi 
jika diperinci setiap aspeknya, maka diketahui bahwa aspek pengamatan yang mendapat skor 3 atau dengan kategori baik hanya 3 aspek yaitu aspek mendengarkan/ memperhatikan penjelasan guru, aspek membuat catatan penting materi pelajaran dan aspek antusias dalam kegiatan pembelajaran. Sedangkan aspek aktif bertanya, menjawab dan berpendapat/berkomentar, aspek bersungguh-sungguh dalam mengerjakan tugas, aspek mandiri dalam mengerjakan tugas, dan aspek mengumpulkan tugas tepat waktu hanya mendapat skor 2 atau dengan kategori kurang. Bahkan ada aspek pengamatan yang mendapat skor 1 atau dengan kategori amat kurang yaitu aspek mampu merefleksi hasil tugas yang dikerjakan. Dengan demikian ada 3 aspek dengan kategori baik, 4 aspek dengan kategori kurang dan 1 aspek dengan kategori amat kurang. Kenyataan tersebut tentu kurang menggembirakan karena masih ada 4 aspek pengamatan dengan kategori kurang dan 1 aspek dengan kategori amat kurang.

Di sisi lain, data hasil tes pada siklus I setelah diterapkannya metode pemberian balikan menunjukkan bahwa nilai tertinggi sebesar 83.90 dan nilai terendah sebesar 67.45. Nilai rerata kelas sebesar 77.55 dan ketuntasan belajar secara klasikal hanya mencapai $80 \%$ atau belum mencapai ketuntasan belajar secara klasikal karena $\leq 85 \%$ seperti yang ditetapkan.

Berdasarkan hal-hal tersebut di atas, perlu dilakukan kegiatan siklus II dengan perbaikan-perbaikan sebagai berikut: (a) guru hendaknya lebih berusaha memotivasi siswa agar aktif dalam kegiatan pembelajaran misalnya dengan memberitahu bahwa perilaku mereka selama kegiatan pembelajaran dinilai, (b) pada saat guru mengoreksi hasil pekerjaan siswa, siswa diberi kegiatan misalnya mengerjakan latihan soal agar kelas tidak ramai, (c) sebaiknya menggunakan pemberian balikan secara ekspositorik untuk memudahkan siswa memperbaiki kesalahannya, (d) guru hendaknya mengelola waktu dengan baik agar skenario pembelajaran sesuai dengan waktu yang ditetapkan. Misalnya jika membutuhkan waktu yang lebih lama pada saat mengoreksi, guru bisa meminta bantuan pengamat sehingga koreksi dapat dilakukan dengan lebih cepat.

Selain memperbaiki hal-hal yang dianggap kurang maksimal yang dilakukan oleh guru pada siklus I, maka untuk hal-hal yang sudah baik, misalnya penggunaan media dan menjelaskan materi dengan baik tetap dipertahankan pada saat pelaksanaan siklus II. Hal ini dilakukan agar siswa aktif dalam kegiatan pembelajaran dan pencapaian kompetensi mereka meningkat.

\section{Hasil Penelitian Siklus II \\ 1. Perencanaan}

Kegiatan perencanaan pada siklus II dilakukan pada minggu ke-2 bulan Agustus tahun 2014 yaitu antara tanggal 18 Agustus sampai dengan 23 Agustus 2014. Berdasarkan hasil refleksi siklus I, disusun Rencana Pelaksanaan Pembelajaran (RPP) siklus II dengan metode pemberian balikan yang dilaksanakan selama 4 jam pelajaran untuk satu kali pertemuan sesuai dengan jadwal pelajaran. Karena siklus II ini dilaksanakan bertepatan dengan bulan puasa maka durasi pembelajaran hanya selama 120 menit. Materi pelajaran yang disajikan tentang Penyusunan jadwal perjalanan dinas pimpinan. Indikator keberhasilan yang ditetapkan adalah jadwal perjalanan telah dibuat dan dikonfirmasikan kepada pejalan. Untuk memperjelas penyampaian materi pelajaran, pada tahap ini juga disiapkan media berupa media format jadwal perjalanan dinas pimpinan dan cara pengisiannya dalam bentuk power point.

Selanjutnya disusun lembar kerja siswa berupa tugas individu untuk menyusun jadwal perjalanan dinas pimpinan. Agar 
pekerjaan siswa lebih cepat diselesaikan, maka disiapkan format jadwal perjalanan dinas pimpinan dan siswa diminta mengerjakan tugasnya pada format tersebut. Hasil pekerjaan siswa akan dikoreksi dengan menggunakan metode pemberian balikan secara ekspositorik.

Untuk mengetahui pencapaian kompetensi siswa pada tahap ini disusun instrument tes siklus II yang terdiri dari kisi-kisi, soal, kunci jawaban, pedoman penskoran, rumus penghitungan nilai siswa dan lembar penilaian. Nilai akhir siswa diperoleh dari penjumlahan nilai kognitif, nilai afektif, dan nilai psikomotoris dengan ketentuan 30\% ranah kognitif, 20\% ranah afektif dan 50\% ranah psikomotoris. Siswa dikatakan tuntas belajar atau kompeten jika nilai akhir yang diperoleh $\geq 75$. Ketuntasan belajar secara klasikal ditetapkan jika jumlah siswa yang tuntas belajar (kompeten) $\geq 85 \%$ dari jumlah siswa yang mengikuti tes.

Pengamatan terhadap aktivitas siswa dan guru selama kegiatan pembelajaran menggunakan lembar pengamatan seperti yang digunakan pada siklus I yaitu berbentuk tabel pengamatan dan catatan lapangan. Tabel pengamatan berisi 8 aspek pengamatan terhadap aktivitas siswa. Pengamat mengisikan skor untuk setiap aspek dengan cara memberi tanda $(\sqrt{ })$ pada skor yang dipilih. Catatan lapangan untuk mencatat aktivitas guru selama kegiatan pembelajaran. Pengamat mencatat hal-hal yang dirasa sudah baik atau yang perlu diperbaiki.

\section{Pelaksanaan}

Kegiatan pembelajaran siklus II dilaksanakan pada hari Senin, tanggal 25 Agustus 2014 di kelas XII APk-2 pada jam pelajaran ke-1 sampai dengan ke-4 atau selama 4 jam pembelajaran dengan durasi waktu selama 120 menit untuk satu kali tatap muka. Kebetulan siklus II ini dilaksanakan pada bulan puasa sehingga waktu pelajaran lebih pendek, per jamnya 30 menit. Karena tidak ada kegiatan upacara dan koordinasi, maka jam pelajaran yang biasanya dilaksanakan pada jam ke 3 sampai dengan jam ke 6 diajukan pada jam ke 1 sampai dengan jam ke 4.

Kegiatan pembelajaran pada siklus II mengacu pada rencana pelaksanaan pembelajaran yang sudah direvisi untuk memperbaiki kekurangan yang ada pada siklus I agar tidak terulang lagi. Seperti pada siklus I, pada siklus II ini peneliti juga bertindak sebagai guru dan Ibu Dra. Tutik Aminah sebagai pengamat. Hari itu semua siswa hadir sejumlah 40 orang.

Untuk mengingatkan lagi tentang materi pelajaran pada minggu lalu yang membahas tentang Surat Tugas untuk perjalanan dinas pimpinan, guru bertanya kepada siswa tentang bagian-bagian dari Surat Tugas. Tak lupa guru menegaskan agar siswa aktif dalam kegiatan pembelajaran, karena guru akan memberikan penilaian untuk perilaku siswa selama kegiatan pembelajaran. Kali ini sekitar 8 siswa sudah berani untuk mengangkat tangannya ingin menjawab pertanyaan. Sebagian besar yang lain masih belum berani. Mengetahui hal tersebut, guru mengatakan bahwa mereka tidak perlu takut menjawab, karena jika jawaban mereka salah, mereka tetap mendapatkan nilai plus atau poin. Mendengar hal itu sebagian besar siswa antusias mengangkat tangannya. Akhirnya guru menunjuk satu persatu siswa untuk menjawab. Siswa yang tidak mendapat giliran menjawab tidak perlu kecewa karena masih ada kesempatan berikutnya.

Kemudian guru membagikan format jadwal perjalanan dinas kepada siswa untuk dicermati dan diberikan tanggapan. Beberapa siswa yang tadi belum mendapat giliran untuk menjawab pertanyaan diberi kesempatan untuk memberikan pendapatnya. Pendapat mereka sama yaitu format jadwal perjalanan dinas pimpinan hampir sama dengan format agenda kegiatan pimpinan. Guru membenarkan hal tersebut. 
Selanjutnya guru menjelaskan tentang tujuan dan langkah-langkah pembelajaran serta garis besar materi pelajaran. Guru menampilkan contoh format jadwal perjalanan dinas dan menjelaskan serta memberikan contoh secara langsung cara mengisi format perjalanan dinas tersebut. Jika siswa kurang jelas, guru mempersilakan mereka untuk bertanya. Kali ini siswa yang ingin bertanya banyak sekali, tapi pertanyaan mereka hampir sama dengan pertanyaan yang diajukan oleh Ike, Purnomo dan Kristin. Ike menanyakan tentang cara pegisian kolom tempat, Purnomo menanyakan cara penulisan waktu jika hari dan tanggalnya sama, dan Khatrin menanyakan tentang pengisian kolom keterangan. Sebelum menjawab pertanyaan, guru memberi kesempatan kepada siswa yang lain untuk menjawab pertanyaan. Satu per satu pertanyaan ditawarkan kepada siswa yang lain untuk menjawab dan mereka sangat antusias untuk mendapatkan kesempatan menjawab. Akhirnya guru menunjuk siapa yang harus menjawab. Ketiga pertanyaan yang diajukan dapat dijawab dengan benar oleh Inka, Nevada, dan Maratus.

Setelah penjelasan materi dan tanya jawab, guru membagikan soal tugas menyusun jadwal perjalanan dinas pimpinan kepada siswa dan dikerjakan pada format jadwal perjalanan dinas. Pada saat mengerjakan, guru berkeliling untuk mengamati kegiatan siswa. Sesuai dengan batas waktu yang telah ditentukan, siswa mengumpulkan hasil pekerjaannya kepada guru untuk dikoreksi.

Guru meminta bantuan kepada pengamat untuk mengoreksi hasil pekerjaan siswa agar pelaksanaan koreksi dapat dilakukan dengan cepat dan siswa dapat segera memperbaiki pekerjaannya yang salah. Pada siklus II ini pemberian balikan dilakukan dengan cara ekspositorik yaitu dengan cara memberi symbol $(\sqrt{ })$ untuk jawaban yang benar dan melingkari jawaban yang salah sekaligus memberi catatan tentang bagaimana membetulkan kesalahan tersebut. Hal ini dimaksudkan agar siswa lebih mudah dan cepat untuk memperbaiki kesalahannya. Ada 6 orang siswa yang hasil pekerjaannya masih terdapat kesalahan. Empat siswa di antaranya hanya melakukan kesalahan pada penulisan kolom keterangan dan setelah diperbaiki, guru langsung menyatakan sudah betul, sedangkan dua siswa yang lain yaitu Ita dan Noviana masih banyak mengalami kesalahan. Guru memanggil keduanya dan memberikan penjelasan per individu. Selama kegiatan koreksi dan perbaikan pekerjaan dilaksanakan, guru meminta siswa lain untuk mengerjakan soal latihan yang ada di buku modul. Di akhir kegiatan inti pembelajaran, guru memberikan tes siklus II.

Sebelum mengakhiri kegiatan pembelajaran guru menyimpulkan materi pelajaran bersama siswa dan memberi tugas pada siswa untuk mengetik hasil tugas pada hari itu dengan komputer dan diserahkan pada minggu depan. Guru menutup pelajaran dengan mengucapkan salam.

\section{Pengamatan}

Kegiatan pengamatan pada siklus II dilakukan oleh Ibu Dra. Tutik Aminah. Waktunya bersamaan dengan pelaksanaan kegiatan pembelajaran. Hasil pengamatan dapat dilihat pada tabel 4.3 
Tabel 4.3 Hasil Pengamatan Kegiatan Pembelajaran Siklus II

\begin{tabular}{|c|c|c|c|c|c|}
\hline \multirow{2}{*}{ No. } & \multirow{2}{*}{ Aktivitas Siswa yang diamati } & \multicolumn{4}{|c|}{ Skor } \\
\hline & & 1 & 2 & 3 & 4 \\
\hline 1. & Mendengarkan / memperhatikan penjelasan guru & & & & $\sqrt{ }$ \\
\hline 2. & Aktif bertanya, menjawab dan berpendapat / berkomentar & & & $\sqrt{ }$ & \\
\hline 3. & Membuat catatan penting materi pelajaran & & & $\sqrt{ }$ & \\
\hline 4. & Bersungguh-sungguh dalam mengerjakan tugas & & & & $\sqrt{ }$ \\
\hline 5. & Mandiri dalam mengerjakan tugas & & & $\sqrt{ }$ & \\
\hline 6. & Mengumpulkan tugas tepat waktu & & & $\sqrt{ }$ & \\
\hline 7. & Mampu merefleksi hasil tugas yang dikerjakan & & & $\sqrt{ }$ & \\
\hline 8. & Antusias dalam kegiatan pembelajaran & & & & $\sqrt{ }$ \\
\hline & JUMLAH & & & 15 & 12 \\
\hline
\end{tabular}

Berdasarkan data tersebut diketahui bahwa aspek mendengarkan/memperhatikan penjelasan guru memperoleh skor 4, aspek aktif bertanya, menjawab dan berpendapat/ berkomentar memperoleh skor 3, aspek membuat catatan penting materi pelajaran memperoleh skor 3, aspek bersungguhsungguh dalam mengerjakan tugas memperoleh skor 4, aspek mandiri dalam mengerjakan tugas memperoleh skor 3 , aspek mengumpulkan tugas tepat waktu memperoleh skor 3, aspek mampu merefleksi hasil tugas yang dikerjakan memperoleh skor 3, dan aspek antusias dalam kegiatan pembelajaran memperoleh skor 4. Jadi jumlah skor yang diperoleh dari hasil pengamatan pada siklus II adalah 27. Kategori untuk aktivitas siswa dengan skor 27 adalah "amat baik".

\section{Data Hasil Tes Siklus II}

Hasil tes siklus II setelah dikoreksi kemudian dianalisis melalui lembar analisis penilaian hasil tes siklus II. Data hasil tes siklus II disajikan dalam bentuk tabel 4.4 sebagai berikut:

Tabel 4.4. Data Hasil Tes Siklus II

\begin{tabular}{|c|c|c|c|c|c|c|c|c|c|}
\hline \multirow[t]{2}{*}{ No } & \multirow{2}{*}{$\begin{array}{ll}\text { Nama Siswa } & \text { Aspek Nilai } \\
\end{array}$} & \multicolumn{2}{|c|}{ Kognitif } & \multicolumn{2}{|c|}{ Afektif } & \multicolumn{2}{|c|}{ Psikomotoris } & \multirow{2}{*}{$\begin{array}{c}\text { NILAI } \\
\text { AKHIR }\end{array}$} & Ketuntasan \\
\hline & & Nilai & $30 \%$ & Nilai & $20 \%$ & Nilai & $50 \%$ & & Ya Tidak \\
\hline 1. & FITRI NURUL KOTIMAH & 90 & 27 & 92 & 18.4 & 90 & 45 & 90.4 & $\sqrt{ }$ \\
\hline 2. & FITRIA SARI & 80 & 24 & 88 & 17.6 & 82.5 & 41.25 & 82.85 & $\sqrt{ }$ \\
\hline 3. & HENY TRI ERNAWATI & 85 & 25.5 & 84 & 16.8 & 95 & 47.5 & 89.8 & $\sqrt{ }$ \\
\hline 4. & IDA ROSITA & 90 & 27 & 84 & 16.8 & 82.5 & 41.25 & 85.05 & $v$ \\
\hline 5. & INDAH DWI ANISA & 70 & 21 & 76 & 15.2 & 70 & 35 & 71.2 & $\sqrt{ }$ \\
\hline 6. & INDRI ERNAWATI & 80 & 24 & 80 & 16 & 82.5 & 41.25 & 81.25 & $v$ \\
\hline 7. & INTAN ARUMNINGTYAS & 80 & 24 & 84 & 16.8 & 82.5 & 41.25 & 82.05 & 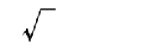 \\
\hline 8 & INTAN PERMATA SARI & 80 & 24 & 80 & 16 & 70 & 35 & 75 & $\sqrt{ }$ \\
\hline 9. & IRWAN SYAFI'IE & 85 & 25.5 & 80 & 16 & 85 & 42.5 & 84 & $\sqrt{ }$ \\
\hline 10 & JULIANI & 80 & 24 & 84 & 16.8 & 80 & 40 & 80.8 & $\sqrt{ }$ \\
\hline 11 & KARTIKA SEKAR HARUM & 90 & 27 & 84 & 16.8 & 82.5 & 41.25 & 85.05 & $\sqrt{ }$ \\
\hline 12 & KHARISMA DIENNA SAKHOFI & 90 & 27 & 84 & 16.8 & 82.5 & 41.25 & 85.05 & $\sqrt{ }$ \\
\hline 13 & KIKI PANGESTU & 75 & 22.5 & 76 & 15.2 & 80 & 40 & 77.7 & $\sqrt{ }$ \\
\hline 14 & KRISTYA NINGRUM & 80 & 24 & 84 & 16.8 & 82.5 & 41.25 & 82.05 & $\sqrt{ }$ \\
\hline 15 & LILIS SURYANI & 80 & 24 & 84 & 16.8 & 95 & 47.5 & 88.3 & $\sqrt{ }$ \\
\hline 16 & LINDA EKA UMMI K. & 80 & 24 & 80 & 16 & 82.5 & 41.25 & 81.25 & $\sqrt{ }$ \\
\hline 17 & LINDA ROHAYATI & 85 & 25.5 & 84 & 16.8 & 82.5 & 41.25 & 83.55 & $\sqrt{ }$ \\
\hline 18 & LUCKY ANANTA PRIBADI & 80 & 24 & 80 & 16 & 80 & 40 & 80 & $\sqrt{ }$ \\
\hline 19 & LUSI SETIANINGSIH & 90 & 27 & 96 & 19.2 & 87.5 & 43.75 & 89.95 & $\sqrt{ }$ \\
\hline
\end{tabular}




\begin{tabular}{|c|c|c|c|c|c|c|c|c|c|}
\hline 20 & LUSIANA DEWI ERMALA & 80 & 24 & 80 & 16 & 72.5 & 36.25 & 76.25 & $\sqrt{ }$ \\
\hline 21 & MARATUS SHOLIKAH & 80 & 24 & 84 & 16.8 & 82.5 & 41.25 & 82.05 & $\sqrt{ }$ \\
\hline 22 & MARATUS SHOLIKAH & 75 & 22.5 & 80 & 16 & 87.5 & 43.75 & 82.25 & r \\
\hline 23 & MEGA FEBRIANI & 75 & 22.5 & 84 & 16.8 & 67.5 & 33.75 & 73.05 & $\sqrt{ }$ \\
\hline 24 & MIA SURYA DEWI & 85 & 25.5 & 80 & 16 & 85 & 42.5 & 84 & $\gamma$ \\
\hline 25 & NADIA ROHAGIA SUWITO P . & 90 & 27 & 80 & 16 & 90 & 45 & 88 & \\
\hline 26 & NANCY PUTRI UTAMI & 90 & 27 & 88 & 17.6 & 87.5 & 43.75 & 88.35 & \\
\hline 27 & NI'MA NASIH & 75 & 22.5 & 92 & 18.4 & 70 & 35 & 75.9 & \\
\hline 28 & NIMAS AYU NUR ZAKIYYAH & 85 & 25.5 & 84 & 16.8 & 87.5 & 43.75 & 86.05 & \\
\hline 29 & NITA AYU MAWARNI & 75 & 22.5 & 92 & 18.4 & 70 & 35 & 75.9 & \\
\hline 30 & NITA KRISTIANA & & 90 & 27 & 92 & 18.4 & 77.5 & 38.75 & \\
\hline 31 & NITA PRASETYANI & 90 & 27 & 84 & 16.8 & 85 & 42.5 & 86.3 & \\
\hline 32 & NOVI ANDRIANI & 85 & 25.5 & 96 & 19.2 & 95 & 47.5 & 92.2 & \\
\hline 33 & NOVIA FAMILA ISTI & 90 & 27 & 88 & 17.6 & 77.5 & 38.75 & 83.35 & \\
\hline 34 & NOVIANA ANDRIYANI & 90 & 27 & 88 & 17.6 & 82.5 & 41.25 & 85.85 & \\
\hline 35 & NOVITA & 90 & 27 & 92 & 18.4 & 82.5 & 41.25 & 86.65 & $\sqrt{ }$ \\
\hline 36 & NOVITA ANDIKASARI & 80 & 24 & 92 & 18.4 & 77.5 & 38.75 & 81.15 & $\sqrt{ }$ \\
\hline 37 & NUR LELAH & 85 & 25.5 & 88 & 17.6 & 90 & 45 & 88.1 & $\checkmark$ \\
\hline 38 & NURUL HIDAYATI & 85 & 25.5 & 88 & 17.6 & 82.5 & 41.25 & 84.35 & $v$ \\
\hline 39 & PRIMA AYU NURIZKA & 90 & 27 & 84 & 16.8 & 82.5 & 41.25 & 85.05 & $\sqrt{ }$ \\
\hline 40 & PRISKA ARINANDA YUNI F. & 90 & 27 & 84 & 16.8 & 92.5 & 46.25 & 90.05 & \\
\hline & Jumlah & & & & & & & 3334.3 & \\
\hline
\end{tabular}

Berdasarkan data di atas, diketahui bahwa siswa meraih nilai tertinggi sebesar 92.20, nilai terendah sebesar 71.20, nilai rerata kelas sebesar 83.58 dan hasil penghitungan untuk ketuntasan belajar klasikal mencapai 95\%.

\section{Refleksi}

Berdasarkan data hasil pengamatan pada saat kegiatan pembelajaran siklus II dengan menerapkan metode pemberian balikan, secara garis besar dapat dikatakan bahwa aktivitas siswa tergolong amat baik karena memperoleh skor sebesar 27. Jika diperinci setiap aspeknya, maka diketahui bahwa aspek pengamatan yang mendapat skor 4 atau dengan kriteria amat baik sebanyak 3 aspek yaitu aspek mendengarkan / memperhatikan penjelasan guru, aspek bersungguh-sungguh dalam mengerjakan tugas, dan aspek antusias dalam kegiatan pembelajaran. Sedangkan aspek yang memperoleh skor 3 atau dengan kriteria baik sebanyak 5 aspek yaitu aspek aktif bertanya, menjawab dan berpendapat/berkomentar, aspek membuat catatan penting materi pelajaran, aspek mandiri dalam mengerjakan tugas, dan aspek mengumpulkan tugas tepat waktu mendapat. Tentu hal ini sangat menggembirakan karena tidak ada aspek dengan kriteria kurang atau amat kurang.

Di sisi lain, data hasil tes pada siklus II dengan menerapkan metode pemberian balikan menunjukkan bahwa nilai tertinggi sebesar 92.20, nilai terendah sebesar 71.20, nilai rerata kelas sebesar 83.58 dan ketuntasan belajar secara klasikal mencapai $95 \%$ atau ketuntasan belajar secara klasikal telah tercapai karena melebihi $85 \%$ seperti yang ditetapkan.

Berdasarkan hal tersebut di atas, dapat dikatakan bahwa guru telah mampu dalam mengelola kegiatan pembelajaran dengan menerapkan metode pemberian balikan karena guru telah melaksanakan tugasnya dengan baik sehingga hal ini memotivasi siswa untuk aktif dalam kegiatan pembelajaran. Akibatnya, pencapaian kompetensi mereka mengalami peningkatan. 


\section{PEMBAHASAN}

Pencapaian kompetensi siswa yang rendah dan siswa kurang aktif dalam kegiatan pembelajaran adalah permasalahan yang terjadi di kelas XII APk-2 pada semester ganjil tahun pelajaran 2014/2015, khususnya pada saat mereka mengikuti pembelajaran standar kompetensi Mengatur Perjalanan Bisnis. Setelah dilakukan evaluasi terhadap data hasil tes dan data hasil pengamatan yang dilakukan sebelum tindakan, maka diketahui bahwa penyebab permasalahan tersebut adalah guru belum mengelola kegiatan pembelajarannya dengan baik, terutama dalam hal penilaian. Oleh karena itu penelitian ini didesain dengan model penelitian tindakan kelas karena bertujuan untuk memperbaiki kegiatan pembelajaran. Adapun perbaikan kegiatan pembelajaran yang dimaksudkan dalam penelitian ini adalah dengan menerapkan metode pemberian balikan.

Dalam penelitian ini, data pencapaian kompetensi siswa diperoleh dari nilai hasil tes membuat agenda pimpinan pada siklus I dan menyusun jadwal perjalanan dinas pimpinan pada siklus II. Tes yang dilakukan bertujuan untuk mengetahui nilai siswa pada ranah kognitif, ranah afektif, dan ranah psikomotoris. Ketuntasan belajar siswa untuk setiap ranah ditentukan bahwa siswa dinyatakan tuntas belajar jika nilai yang diperoleh siswa $\geq 75$ atau dengan persentase $\geq 75 \%$ dan ketuntasan belajar klasikal untuk setiap ranah tercapai jika persentasenya $>85 \%$. Sedangkan untuk nilai akhir siswa diperoleh dari hasil penjumlahan nilai ranah kognitif, ranah afektif, dan ranah psikomotoris. Besarnya persentase nilai ranah kognitif adalah $30 \%$, nilai ranah afektif sebesar $20 \%$ dan nilai ranah psikomotoris sebesar 50\%. Siswa dikatakan tuntas belajar untuk nilai akhir ini ditentukan jika nilai yang diperoleh siswa $\geq 75$ atau dengan persentase $\geq 75 \%$ dan ketuntasan belajar klasikal untuk nilai akhir tercapai jika persentasenya $\geq 85 \%$.

Pengamatan dalam penelitian ini dilakukan bersamaan dengan kegiatan pembelajaran berlangsung. Untuk memperoleh data pengamatan dipergunakan lembar pengamatan kegiatan pembelajaran. Aspek yang diamati adalah aktivitas siswa dan guru dalam kegiatan pembelajaran. Tujuan dari pengamatan ini adalah untuk mengetahui halhal yang dilakukan oleh siswa dan guru selama diterapkannya metode pemberian balikan. Apakah hal-hal yang dilakukan sudah mendukung atau tidak mendukung terhadap keberhasilan penerapan metode pemberian balikan. Setelah itu dilakukan evaluasi terhadap hasil pengamatan untuk menentukan bentuk-bentuk tindakan perbaikan terhadap kekurangan-kekurangan yang terjadi dan mempertahankan hal yang positip yang akan dilaksanakan pada siklus berikutnya.

Berdasarkan hasil penelitian pada siklus I dan siklus II diperoleh temuantemuan sebagai berikut:

\section{Data Hasil Tes Siklus I dan Siklus II}

Distribusi hasil tes siklus I dan siklus II disajikan dalam tabel 4.5.

Tabel 4.5 Distribusi Hasil Tes Siklus I dan Siklus II

\begin{tabular}{clcc}
\hline No. & \multicolumn{1}{c}{ Aspek Hasil } & Siklus I & Siklus II \\
\hline 1. & Nilai tertinggi & 83.90 & 92.20 \\
2. & Nilai terendah & 67.45 & 71.20 \\
3. & Nilai Rerata Kelas & 77.55 & 83.58 \\
4. & \% Ketuntasan Belajar Klasikal & $80 \%$ & $95 \%$ \\
\hline
\end{tabular}


Bila digambarkan dalam bentuk histogram maka tampak pada gambar :

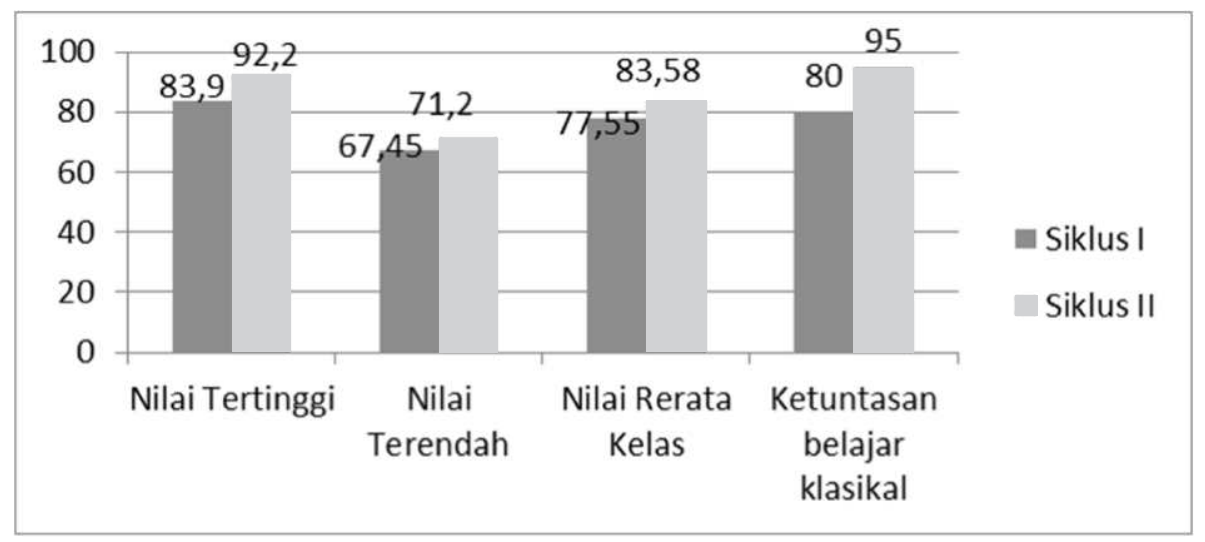

Gambar 4.1. Histogram Distribusi Hasil Tes

Berdasarkan data pada tabel dan gambar histogram di atas menunjukkan bahwa ada peningkatan untuk pencapaian kompetensi siswa di setiap aspek hasil tes pada siklus II dibanding siklus I. Nilai tertinggi pada siklus I sebesar 83.90 dan pada pada siklus II menjadi 92.20 atau meningkat sebanyak 8.3 poin. Nilai terendah pada siklus I sebesar 67.45 dan pada siklus II menjadi 71.20 atau meningkat sebanyak 3.75 poin. Nilai rerata kelas pada siklus I sebesar 77.55, dan pada siklus II menjadi 83.58 atau meningkat sebanyak 6.03 poin. Ketuntasan belajar klasikal pada siklus I sebesar $80 \%$ atau belum tercapai dan pada siklus II tercapai dengan persentase mencapai $95 \%$ atau meningkat sebesar $15 \%$.

\section{Data Hasil Pengamatan Siklus I dan Siklus II}

Distribusi hasil pengamatan siklus I dan siklus II dapat dilihat pada tabel 4.5.

Tabel 4.5 Distribusi Hasil Pengamatan Siklus I dan Siklus II

\begin{tabular}{llcl}
\hline No. & \multicolumn{1}{c}{ Siklus } & Skor & \multicolumn{1}{c}{ Kategori } \\
\hline 1. & Siklus I & 18 & Baik \\
2. & Siklus II & 27 & Amat Baik \\
\hline
\end{tabular}

Perbandingan perolehan skor hasil pengamatan pada siklus I dan siklus II jika disaji- kan dalam bentuk diagram lingkaran tampak sebagai berikut:

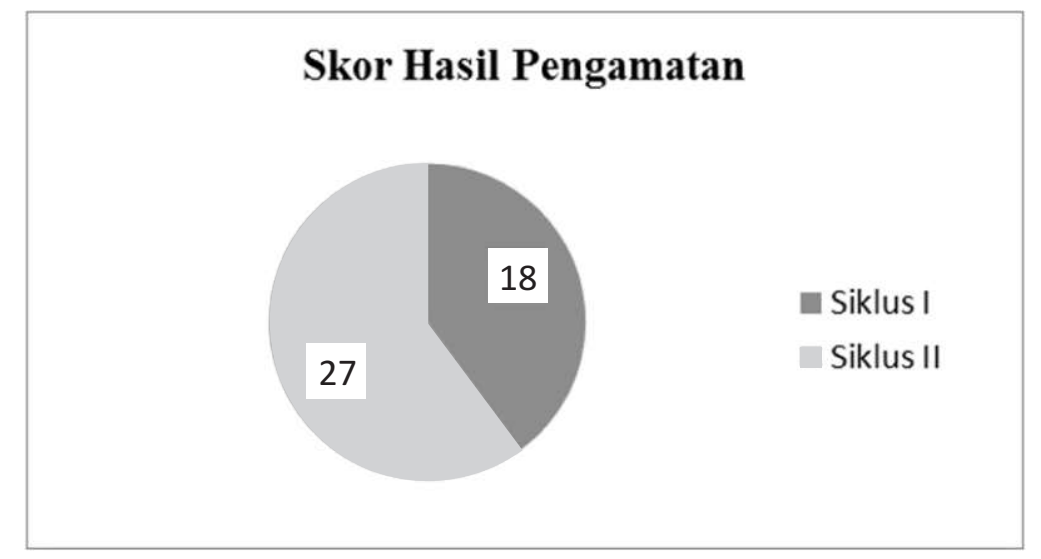

Gambar 4.2. Diagram Lingkaran Perbandingan Perolehan Skor 
Berdasarkan data pada tabel dan diagram lingkaran di atas menunjukkan bahwa perolehan skor hasil pengamatan siklus II meningkat jika dibandingkan dengan siklus I yaitu sebesar 9 skor. Sedangkan untuk kategori aktivitas siswa juga meningkat dari kategori baik pada siklus I menjadi kategori amat baik pada siklus II. Hasil catatan lapangan pelaksanaan siklus II ketahui bahwa guru telah melakukan kegiatan pembelajaran dengan metode pemberian balikan dengan baik.

\section{PENUTUP}

\section{Simpulan}

Berdasarkan hasil penelitian yang telah dipaparkan dalam dua siklus, hasil seluruh analisis dan pembahasan yang telah dilakukan, peneliti menyimpulkan bahwa:

1. Terdapat peningkatan kompetensi mengatur perjalanan bisnis pada siswa kelas XII APk-2 SMK Negeri 1 Magetan tahun pelajaran 2014/2015 setelah diadakan penelitian tindakan dengan menerapkan metode Pemberian Balikan. Hal ini ditunjukkan dengan meningkatnya nilai tertinggi yang diperoleh siswa dari 83.90 pada siklus I menjadi 92.20 pada siklus II, atau meningkat sebanyak 8.3 poin. Nilai terendah dari 67.45 pada siklus I menjadi 71.20 pada siklus II, atau meningkat sebanyak 3.75 poin. Nilai rerata kelas dari 77.55 pada siklus I menjadi 83.58 pada siklus II atau meningkat sebanyak 6.03 poin. Ketuntasan belajar klasikal dari $80 \%$ atau belum tercapai pada siklus I menjadi $95 \%$ atau tercapai pada siklus II, dan meningkat sebesar $15 \%$.

2. Terdapat peningkatan motivasi siswa kelas XII APk-2 SMK Negeri 1 Magetan tahun pelajaran 2014/2015 untuk aktif dalam kegiatan pembelajaran standar kompetensi Mengatur Perjalanan Bisnis setelah diadakan penelitian tindakan dengan menerapkan metode Pemberian
Balikan. Hal ini ditunjukkan dengan meningkatnya perolehan skor hasil pengamatan dari 18 pada siklus I menjadi 25 pada siklus II, atau meningkat sebanyak 7 skor. Kategori aktivitas siswa juga meningkat dari kategori baik pada siklus I menjadi kategori amat baik pada siklus II.

\section{Saran}

Dari hasil penelitian yang diperoleh, maka peneliti menuliskan saran sebagai berikut :

1. Metode pemberian balikan dapat dijadikan sebagai salah satu alternatif metode pembelajaran yang dapat dipilih oleh guru dalam melaksanakan pembelajaran kompetensi mengatur perjalanan bisnis karena telah terbukti mampu meningkatkan pencapaian kompetensi mengatur perjalanan bisnis dan motivasi siswa untuk aktif dalam kegiatan pembelajaran.

2. Hasil penelitian ini dapat dijadikan motivasi bagi para guru untuk melakukan penelitian tindakan kelas dengan tindakan yang sama atau tindakan yang berbeda guna keberhasilan kegiatan pembelajaran.

\section{DAFTAR PUSTAKA}

Ali, Mohammad. (1993). Srategi Penelitian Pendidikan. Bandung: Angkasa.

Arifin, Zaenal. (2008). Dasar-Dasar Penulisan Karya Ilmiah. Jakarta: PT. Grasindo.

Arikunto, Suharsimi. (2002). Prosedur Penelitian (Suatu Pendekatan Praktek). Jakarta: Rineka Cipta.

Arikunto, Suharsimi et al. (2007). Penelitian Tindakan Kelas. Jakarta:Bumi Aksara.

Departemen Pendidikan Nasional. (2004). Kurikulum SMK Edisi 2004 Bidang Keahlian Bisnis dan Manajemen Program Keahlian Administrasi Perkantoran, Direktorat Jenderal Pendidikan Dasar dan Menengah, 
Direktorat Pendidikan Menengah Kejuruan.

Djamarah, Syaiful Bahri dan Aswan Zain. (2006). Strategi Belajar Mengajar. Jakarta: PT. Rineka Cipta.

Hamalik, Oemar. (2003). Proses Belajar Mengajar. Jakarta: PT. Bumi Aksara.

Majid, Abdul. (2008). Perencanaan Pembelajaran, Mengembangkan Standar Kompetensi Guru. Bandung: PT. Remaja Rosdakarya.

Makmun, Abin Syamsudin. (2007). Psikologi Pendidikan, Perangkat, Sistem Pengajaran Modul. Bandung: PT. Remaja Rosdakarya.

Mulyasa, E. (2006). Kurikulum Berbasis Kompetensi, Konsep, Karakteristik dan Implementasi. Bandung: PT. Remaja Rosdakarya. . (2006). Kurikulum yang Disempurnakan, Pengembangan Standar Kompetensi dan Kompetensi Dasar. Bandung: PT. Remaja Rosdakarya.

Nur, Muh. (2001). Pemotivasian Siswa untuk Belajar. Surabaya: University Press. Universitas Negeri Surabaya.

Prayitno. (2014). Dasar Teori dan Praksis Pendidikan, Jakarta: PT. Grasindo.

Rachman, Saiful et al. (2006). Penelitian Tindakan Kelas dan Penulisan Karya Ilmiah. Surabaya: SIC bekerja sama dengan Dinas P dan K Propinsi Jawa Timur.

Rustiyah, N. K. (1991). Strategi Belajar Mengajar. Jakarta: Rineka Cipta.

Safary. (2005). Penulisan Butir Soal Berdasarkan Penilaian Berbasis Kompetensi, Jakarta: Asosiasi Pengawas Sekolah Indonesia Departemen Pendidikan Nasional.
Sanjaya, Wina. (2006). Pembelajaran dalam Implementasi Kurikulum Berbasis Kompetensi. Jakarta: Kencana Prenada Media Group. - (2008). Perencanaan dan Desain Sistem Pembelajaran. Jakarta: Kencana Prenada Media Group.

Sudjana, Nana. (2002). Metoda Statistika. Bandung: Tarsito. - (2006). Penilaian Hasil Proses Belajar Mengajar. Bandung: PT. Remaja Rosdakarya.

Sudrajat, Akhmad. (2008). Penilaian Hasil Pembelajaran http://smacepiring.wordpress.com/ diakses tanggal 06/06/2014. . (2014). Beda Strategi,

Model, Pendekatan, Metode, dan Teknik Pembelajaran .

http://smacepiring.wordpress.com/06/ 06/2014.

Sugiyanto. (2007). Modul PLPG ModelModel Pembelajaran Inovatif. Surakarta: Panitia Sertifikasi Guru Rayon 13.

Suparno dan Waras Kamdi. (2008). Pengembangan Profesionalitas Guru. Malang: Panitia Sertifikasi Guru Rayon 15 .

Sutrisno dan Liyah Tjarliyah. (2008). Mengatur Perjalanan Dinas Pimpinan, Bandung: Yudhistira.

Suyanto, Kasihani KE. (2008). Model-Model Pembelajaran. Malang: Depdiknas Universitas Negeri Malang Panitia Sertifikasi Guru Rayon 15.

The Liang Gie. (1988). Administrasi Perkantoran Modern. Yogjakarta: Supersukses dan Nur Cahaya.

Wursanto, Ig. (2004). Kompetensi Sekretaris Profesional. Yogjakarta: Penerbit Andi. 